\title{
Towards Resilient Residential Buildings and Neighborhoods in Light of COVID-19 Pandemic-The Scenario of Podgorica, Montenegro
}

\author{
Marija Bojović *, Irena Rajković and Svetlana K. Perović (D)
}

check for

updates

Citation: Bojović, M.; Rajković, I.;

Perović, S.K. Towards Resilient

Residential Buildings and

Neighborhoods in Light of COVID-19

Pandemic-The Scenario of

Podgorica, Montenegro. Sustainability

2022, 14, 1302. https://doi.org/

$10.3390 /$ su14031302

Academic Editors: Alenka Fikfak

Saja Kosanović, Matej Nikšič and

Christine Mady

Received: 27 December 2021

Accepted: 19 January 2022

Published: 24 January 2022

Publisher's Note: MDPI stays neutral with regard to jurisdictional claims in published maps and institutional affiliations.

Copyright: (C) 2022 by the authors. Licensee MDPI, Basel, Switzerland. This article is an open access article distributed under the terms and conditions of the Creative Commons Attribution (CC BY) license (https:// creativecommons.org/licenses/by/ $4.0 /)$.
Faculty of Architecture, University of Montenegro, Bulevar Džordža Vašingtona b.b., 81000 Podgorica, Montenegro; irenar@ucg.ac.me (I.R.); svetlana.perovic@ucg.ac.me (S.K.P.)

* Correspondence: marijab@ucg.ac.me

\begin{abstract}
The COVID-19 crisis and new pandemic-oriented everyday life have emphasized the urge to reorganize the way we live and reside, additionally highlighting the already existing socio-spatial problematic that Montenegrin society has been experiencing for thirty years. Since residential space is considered to be vital for physical, mental and social wellbeing, this sudden and global paradigm shift presents an opportunity to redefine the current housing concepts towards greater long-term resilience in the context of present, pandemic and future challenges. The results of the survey of housing users in Podgorica confirmed the need to address this issue. The article discusses a possible model of resilient adaptation of residential buildings and neighborhoods in Podgorica, Montenegro. The model addresses the flexibility of the apartment units, existence of indoor and outdoor common areas for social activities within the building and immediate contact with nature, and it is applicable in the wider territorial context as well. Formulated with the aim of long-term improvement of the concept of housing, the model presents a significant framework for the planning and design of future buildings. The resilient residential model is tested by its application to specific buildings of residential area Blok 5 in Podgorica. This leads to the conclusion that the earlier concepts of housing present in theory and practice in the second half of the twentieth century in Montenegro and the region were more adequate in the context of resilience. As we believe that such improved resilient housing would consequently increase the resilience of the community regarding the challenges it faces currently due to COVID-19, we consider this a long-term contribution of this research.
\end{abstract}

Keywords: resilient housing; COVID-19; flexible apartment unit; rooftop garden; Podgorica

\section{Introduction}

COVID-19 has brought sudden and profound changes to our everyday life, questioning the way we live, work and reside, although we could argue that it only emphasized the existing socio-spatial problematic [1] that Montenegrin society has been experiencing for thirty years. In addition, we have already been witnessing a paradigm shift, affecting our life and work, as a result of a complex set of factors and growing global and local trends intensified by COVID-19. The digitization of services (e-commerce and delivery, e-business and payment) is increasingly reducing the time once devoted to performing tasks related to household maintenance. People work remotely and attend classes at least partially from home. Progressively controlled socialization of children, pre-COVID, was usually taking place in specialized and closed semi-public spaces compared to previous gatherings in the courtyards of residential buildings. Most of our social events, even group physical activities, are now taking place online due to the pandemic. In this newly created current redistribution of time between residential and commercial working space, residential space takes primacy, which indicates its central and vital role in people's lives. This highlights the necessity to rethink, adapt and improve it in order for it to meet the greatly changed needs of its current inhabitants, leaving opportunities for future users to live healthy and 
quality lives as well. Unfortunately, all of these major alterations have not yet been accompanied by redefining the concept of housing or changes in its consideration, planning and design process.

The COVID-19 pandemic may not have caused this paradigm shift itself, but it has significantly accelerated changes that were certainly inevitable. In addition, occasional lockdowns and restrictions on leaving the home have become a reality that inarguably serves as a reminder of the importance of adequate housing for physical, mental and social wellbeing [2]. Due to the lack of adequate space for living and working activities in this already two-year pandemic scenario, especially in the case of living in multi-family housing, we are witnessing, globally and locally, pronounced migration from urban to rural areas in search of freedom of organization in everyday life, but also due to the increased need of returning to nature [3-6]. It is clear that housing plays an integral role in the pandemic, and it is in the response to it [7] that we are especially interested.

Since we consider that the city, and, therefore, housing, should function smoothly in all scenarios, including special conditions and lifestyle changes in the current pandemic and further in post-pandemic time, we can consider COVID-19 as a test of their resilience [8], especially in the context of multi-family residential buildings and residential neighborhoods.

Therefore, the starting premise of the research refers to the need to redefine the concept, planning and design of housing in order for it to form the physical framework for healthy and good living in a challenging pandemic and similar unplanned circumstances. As the city represents continuity [9], and since it has been presumed that the existing housing stock does not sufficiently meet the above conditions, it is necessary to propose mechanisms and ways to transform current multi-family housing and residential areas in the direction of greater and long-term resilience.

The survey of housing users in Podgorica will serve to confirm the premise of insufficient adequacy, equipment, flexibility and adaptability of the existing housing and the need to redefine the general concept of residential planning and design in the case of COVID-19 and similar challenges.

The research aims to formulate a model for achieving the resilience of residential buildings and residential areas regarding the COVID-19 pandemic scenario, through their transformation or initial design, into healthier and more adequate living environments. The model will be a set of guidelines and mechanisms to enable this, further tested through its practical application to the selected residential buildings in Podgorica.

The paper first defines a theoretical framework, which contains a review of the literature on residential resilience in general and in the context of COVID-19. It results in a working definition of a residential building resilient to the current pandemic and future challenges, followed by research methodology and materials. In order to clarify the sociospatial and territorial framework and related issues, the following sections deal with the local context and its specifics from the aspect of collective housing, with a brief comparison of its characteristics in the period of self-managing socialism and a period of transition, today. After analyzing the results of the survey and based on the sublimated conclusions of the research findings, the authors formulate a model of resilient housing to further be applied. The research also points out the necessity of supplementing the role of the architect in the overall process.

\section{Resilient Residential Concepts in Light of the COVID-19 Pandemic}

The major concept of resilience [10] is especially actualized in the context of sustainable urban regeneration in various disciplines and fields of research. Resilience is considered not only a reactive approach but also a proactive long-term mechanism for sustainable socio-economic and institutional transformation [11]. There are numerous definitions of urban resilience, while resilience in general is treated as the ability of a system, community or society to withstand pressure, absorb change, transform, adapt and recover quickly with the preservation of its key structures when exposed to various adversities [12,13]. The principles of resilience are being applied to cities, and the "Resilient Cities" platform 
considers that urban resilience is reflected in the city's ability as a system to develop and thrive despite the chronic or acute stresses to which it is exposed [14]. Meerow et al., deal with a thorough research review on urban resilience in which they ultimately give their own integrative definition of the concept, referring to the ability of the urban system and its components to quickly return to the desired functions in the event of disturbance, and to successfully adapt to change [12]. Lupisek et al., comparably transfer this understanding of resilience to a single building, considering it resilient if it has the ability to quickly adapt to changes in conditions and continue to function smoothly [15].

The discourse on social resilience is similarly framed, and it has been topical in research circles over the last ten years [16]. The response of a society, city or system to future challenges depends on their preparedness, i.e., preparedness of social actors and their capacity to learn from past experiences $[17,18]$. In this context, there is a division of stressors by their type: the first group is concerned with natural hazards and disasters, including the COVID-19 pandemic, the second group addresses long-term stress associated with natural resource management and resource scarcity, while the third includes social change and development, including urban socio-spatial transformation [16,19], which can be very traumatic and are the types of stressors faced by Montenegrin society and the city during the thirty-year long period of transition. This partly suggests the topicality of the issue of resilience in the context of Montenegrin society and space, significantly before the COVID-19 pandemic, as the latest current challenge. In social resilience too, the emphasis is on endurance, adaptability and transformability, which naturally directs us to the theme of the flexibility of the architectural space as the eternal imperative.

This research observes all of the above from the aspect of the impact of the global COVID-19 pandemic on everyday life and the associated space, which is the topic of a large number of scientific papers [20,21]. Additionally, the very issue of residential resilience in the context of the current challenges is increasingly relevant in academia $[1,2,7,22,23]$. Research on this topic covers various aspects as significant in the COVID-19 scenario, from the physical qualities of the residential environment (air quality and ventilation, among other things), the overall physical comfort-air quality and natural light, interior materials, existence of self-cleaning space and contactless technologies [2], importance of greenery in the immediate vicinity of residential buildings for mental and physical health, especially during a pandemic [2,24], to the presence of outdoor and safe indoor spaces for socialization as essential for the well-being and social and mental health of the resident [22]. Moreover, research on housing during COVID-19 re-actualizes the topic of flexible and adaptable architectural space as the space of the future, and the only one that can respond to unpredictable challenges ahead [22,25-28].

The topic of flexibility of architectural space is not new, but it is continuously current, complex and requires changes and additions to the roles of all actors involved in the process. In the 1960s, art abandoned tradition and artists demanded greater audience involvement, leaving their work unfinished and open to partial interpretation of the user, not giving a single, definitive order and solution but instead a multitude of possible answers [29]. Umberto Eco finds such work of art open, emphasizing its importance, among other things, due to the long-term historical usefulness of the concept of openness and thus adaptability and relevance [29]. The emphasis is on the role of the user, interpretation and feedback, i.e., the interactive process between the user and the work. Simultaneously, Yona Friedman, who is known for utopian projects that required significant user participation, was relevant in the European scene. In his first manifesto, "Mobile Architecture" (1958), previously presented at the tenth Congrès Internationaux d'Architecture Moderne (CIAM) in Dubrovnik, he advocated for a new type of mobility of users of the space, who were given the freedom of decision [30]. Such (residential) architecture is "housing at the discretion of the tenants" since the infrastructure that makes it possible is "neither defined nor defining". This right to freedom, individualization in socialization, the right to habitat and to inhabit, to work and participation and the right to appropriation are all contained in Lefebvre's formulation of the right to the city [31], which can be seen more broadly as the right to 
(own) architectural space. The right to adequate housing is formulated by the United Nations, with an emphasis on the right to quality and healthy living space equipped with basic infrastructure, but also on participation in decision-making regarding housing issues at the community and national level [32]. In the context of COVID-19, the UN emphasize the importance of public space for community and social resilience, as well as personal wellbeing, inter alia by proposing linking the "right to the city" and the "right to health" [33]. In this context, public space should be accessible to all at a maximum walking distance of $5 \mathrm{~min}$. In terms of living conditions in residential buildings, it is important to have opportunities to further promote and achieve the flexibility of buildings' facilities and avoid overcrowding. The flexibility of a building is considered here as its adaptability to other purposes as needed in light of the pandemic (sports halls that become temporary hospitals, etc.), while we do not consider adaptability at the level of residential units in terms of new organization of the residential space.

In the time of sustainability as a ubiquitous concept, John Habraken's theory of flexibility of collective housing is being updated again. Habraken advocates the introduction of the user in the design process, and that the user should be given as many rights as possible within the collective housing [34], and that residential space, as a private, personal space, must be adaptable to individual needs. Hence, it is not possible to offer one solution that suits everyone [35]. Although he believes that housing, as a process of solving existential issues, is universally applicable, he still emphasizes a necessary prerequisite for successful implementation, which is the cultivation of the process in an adequate social climate that implies the initial need of each individual for self-cultivation [34] seeing as housing is a cultural act [36]. Such "open buildings" are adequate spaces for the social, economic and technological complexity of our time and the future; they add value and are timeless. Only such architecture can suit modern society—unstable, uncertain and unpredictable [37].

In former Yugoslavia during the 1970s and 1980s, the Belgrade School of Housing was dealing with the concept of flexibility of residential space in multi-family housing through practice and numerous competitions, conferences and consultations [38]. In Montenegro, the residential area Blok 5 (1977-1984) in Podgorica, the first prize-winning design of one of such international competitions, was created on these theoretical starting points, including production on space [39] and the right to the city. The competition entry was submitted under "PRAXIS", which indicated the author's ambition of achieving unity of theory and practice $[9,36]$. As each society produces its own space [39], Blok 5 was designed in the ambiance of self-managing socialism, when both state policy and ideology implied the participation of the individual in decision-making [9,36]. Being open and flexible, this neighborhood was only partially designed for the generation of that time and predominantly for future generations.

The review of relevant research on the key topics for this paper brought together the concept of resilience in architecture in general and the resilience of residential buildings in the context of COVID-19, the discussion on open work in art and architecture and their longterm relevance, the right to the city and to adequate housing, together with flexibility of collective housing and users' participation in the process. The basic theoretical framework for further research is set. Therefore, it is possible to formulate a working definition of a residential building resilient to current (pandemic) and future challenges. We consider that such a facility has to be flexible enough, adaptable but also complete, autonomous, to be able to function smoothly in sudden conditions - today, COVID-19-providing its users with the opportunity to practice the right to adequate housing, which, as such, represents an appropriate physical framework for healthy and good living.

\section{Materials and Methods}

\subsection{Montenegrin Context-Specificity and Impacts}

Montenegro, a country in western-central Balkans, represents the wider socio-spatial context of this research. With a population of 620,000 inhabitants, Montenegro was, from 1945 to 1991, the smallest of six members of Socialist Federal Republic of Yugoslavia. 
Podgorica is the capital, and, with population of over 200,000 inhabitants and growing, it represents the country's largest city. In terms of organization, Yugoslavia was a topbottom, socialist and later self-managing republic, which considered space, besides its people, its most valuable resource and a very essence of the state's existence $[9,36]$. Along with such concept of state policy, the process of urban design and planning took the primary role in distribution of space.

A dramatic inflow of rural population into Montenegrin cities due to the accelerated industrialization of the state after World War II and, consequently, the increase in urban population, created the need for a more intense residential construction. Montenegro recorded the highest extent of urbanization of all the South Slovene states [9]. Basic principles of housing fund construction were grounded in the values of the self-managing socialism "to everyone, according to their work" and "to everyone, according to their needs" [40].

Since the dissolution of SFR Yugoslavia in 1991, Montenegrin society has been experiencing a radical change in the socio-economic and political system for thirty years, that is, the transition from self-managing socialism to neoliberal capitalism. This socioeconomic and political shift was followed by significant overall change in the system of values. Brief comparison of these changes in domain of housing will be presented in the following sections.

\subsubsection{Causal Socio-Spatial Issues in Period of Transition, Enhanced by the} COVID-19 Pandemic

Thirty-year period of transition has been impoverishing primarily all of the complexity of society, i.e., social life and then also the space-city and architectural work, which are being reduced to goods-measured by market and quantitative rather than use (qualitative) value. At the same time, the user of the space is degraded and reduced to the buyer and not the creator or an active participant in the process of creating an appropriate, quality architectural environment. The primary accumulation of capital and the overemphasized desire for fastest turnover and making as much profit as possible have chosen natural and urban space as the most favorable medium [36], which results in their significant degradation. Economic changes have brought about privatization in all domains so that social and state ownership of spatial and economic resources is becoming privatized. The state continues to formally implement the spatial planning process, although significantly influenced by private interests.

In the domain of architecture, the attitude towards space as a commodity significantly impoverishes the complexity of the architectural work. A consequence of the abolition of the previous system of values is the neglect or abandonment of urban and architectural concepts that were valid in the period of self-managing socialism. In the period of transition, there is a certain anarchy, and the typology that is experiencing expansion in that discourse is multi-family housing, designed and built for the market. The state is no longer the investor but private companies, and the buildings are created not in response to the real needs of society but represent the optimal medium for capital turnover. Their functional and aesthetic ranges are low, apartments are sold per square meter and their actual use value is less important. The buildings are designed almost typical, especially in terms of functional organization: there is a lack of housing concept and consideration, residential units are undersized and designed to offer only one possible functional layout and the number of apartments on one floor, within one vertical communication, is significantly higher than the optimal. The density of construction in the newly created residential areas is too high, the buildings are planned and built at insufficient distances from each other and the transitional residential construction is characterized by a significant absence of greenery in the new residential areas (Figure 1), as well as the lack of adequate social infrastructure [41,42]. 

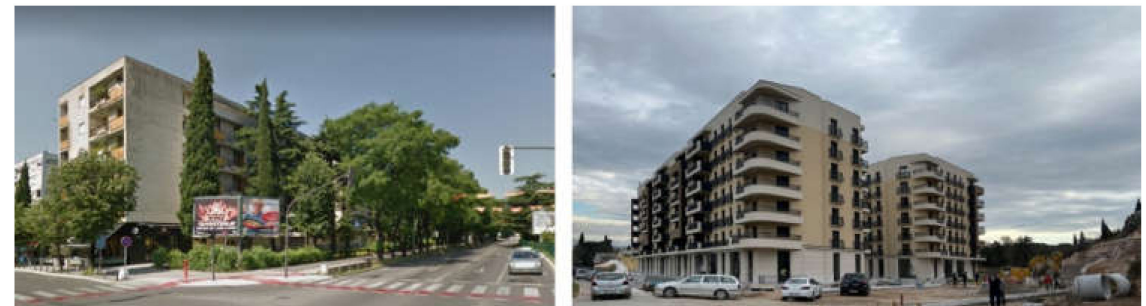

Figure 1. Typical housing block in Podgorica, dating from second half of the 20th century, on the left, compared to typical housing block in period of transition on the right.

All the shortcomings of transitional residential construction are further emphasized during the COVID-19 pandemic, when residential space often became an all-day habitat for the whole family and also a place of work. The limited and fixed organization of the residential unit itself comes to the fore, and users can sense more what are the shortcomings of a multi-family unit in terms of isolation from nature and the inability to spend free time outdoors, even in smaller, controlled groups. If we argue that residential buildings must function smoothly in all sudden circumstances and special conditions, the transitional residential narrative indicates the need for a thorough review of the current approach to collective housing.

\subsubsection{The Concept of Housing during Socialistic Tendency}

As each society produces its own space, i.e., its own representation of space [39], the Montenegrin society in transition is abandoning the urban and architectural concepts of the previous system and is creating its own city and architecture. They represent a reflection of the achieved level of civilization, the responsibility of the individual to the community and vice versa and common responsibility toward their own space and city, that is, the reflection of society and state to the collective agreement, laws and their implementation [9]. The impoverishment of the overall complexity of the architectural work and space happened as expected since the suspension of the previous value system and has led to the creation of a one-dimensional, consumerist society, often burdened with the struggle for basic material existence. Social security and economic stability of the self-governing socialism have been replaced by a variety of unstable, open, nomadic, crisis events, as well as transient and uncertain policies [43]. A review of the key characteristics of multi-family housing in transition indicates a number of shortcomings of the concept, further highlighted during the pandemic period. Nevertheless, the transitional housing stock represents only a part of the total urban residential fabric in Podgorica, while buildings of the second half of the 20th century represent a significant segment.

In socialism, space was a big social project, with the goal of creating a new socialist individual [44]. The state essentially took care of the society and space, their continuous improvement and upgrade, acting as the guarantor of the general interest [9]. Architectural achievements from the socialistic period, commissioned by the state, represent the backbone of cultural heritage and a very important segment of the architectural fund of the 20th century in Montenegro and in the region.

Regarding multi-family residential construction, the second half of the 20th century on the territory of former Yugoslavia, as well as Montenegro, was shaped by plans, designs and construction of new residential blocks for five to ten thousand inhabitants, often completed through general Yugoslav architectural competitions. These blocks resulted from a thoughtful approach to the complex issue of housing from the aspect of human needs, with an emphasis on humaneness, human dimension and the use value of urban and architectural space. The corresponding standards for planning and design, from today's aspect, were simultaneously formulated as a socio-economic, technical and cultural issue, the latter being the field of expected architectural initiative and a chance to achieve fuller consonance and more harmonious relationship between life and space [38]. 
Unlike today's scenario, these residential areas of mature socialism consist of buildings that were planned at adequate distances (which is why today we often have the insertion of new buildings inside that urban tissue), green areas and high greenery were an integral part of the blocks and there was adequately dimensioned social infrastructure and social standard buildings (health centers, nurseries and kindergartens). "New Urbanism" aimed to revive the city as a collective reality, which consequently meant thinking about the "social imperative", i.e., social integration of citizens and their identification with the place of residence, as well as rehabilitation of areas for gathering and recreation and their valorization through adequate servicing [45]. At the level of the building and the apartment as the smallest unit, residential space was the result of thorough consideration of the housing issue, with a broader concept and vision, often providing the opportunity to improve the living habits of its users.

Housing projects of the ' 60 s and ' 80 s of the 20th century were based on anthropological provisions that people are social beings that exist through social relations through existence in the community and in a communal space, that people are active, that is, characterized by a creative aspiration to change and always reach a new and desired space and to see freedom in the opportunity of choice-freedom within the space [38], and, as political beings, people need to participate in the decision-making concerning their own living space.

As Podgorica represents the territorial framework of this research, Blok 5 in Podgorica serves as a local example of a residential area from this period. At a sociologically and politically specific moment for Montenegro, in the period of Yugoslav self-managing socialism when state policy implied the participation of the individual in decision-making, Blok 5 was an example of housing that was in line with the ideology as the emphasis was on flexibility of the buildings, designed as open work. It is due to the theoretical foundations on which this residential block was designed that we choose its buildings to test the resilient residential model in practice.

This was a brief review of the key features of the concept of multi-family buildings and residential areas and attitudes towards the issue of housing in Montenegro in the two social and political systems. Today, through the pandemic prism of perceiving the issue, we believe that more humane living spaces, as well as their use value, are again gaining importance.

\subsection{Data and Methodology Approach}

The structure of this paper consists of two constitutive and complementary parts, theoretical-empirical and practical research. The theoretical part is based on the review of literature and current research on close issues - the concept of resilience in architecture, resilience of residential buildings in general and in the context of the COVID-19 pandemic and the open work or flexibility of the work of architecture as an eternal imperative to practice the right to architectural space. The review of the relevant literature presented in this way provides the theoretical basis that results in the formulation of a working definition of resilient residential buildings in the context of the COVID-19 pandemic and further formation of a model that can achieve this.

The formulation of the model is preceded by the clarification of the local Montenegrin socio-spatial context in order to better understand the inherited discourse from selfmanaging socialism and the consequences of its replacement by transitional one. The pandemic scenario comes on top of the existing problems in terms of housing, which have been present for thirty years, further emphasizing the need to solve existing issues.

A survey was conducted in this paper targeting the residents of Podgorica, and the survey data of 170 individual respondents were collected in November of 2021 via Google forms application. The questions were related to the quality of everyday life during COVID-19 pandemic and the associated restrictions in terms of organization of life and work, especially from the aspect of the lockdown and performing all-day obligations out of the living space. More specifically, first seven questions we related to the general characteristics of the respondents (Table 1), followed by three questions on the topic of work 
and study management during the lockdown. Questions that came after gathered data on advantages and disadvantages of living in residential building and one-family housing regarding contact with nature, freedom of movement and practicing social activities, as well as the attitudes towards green rooftop gardens and flexible apartment units.

Table 1. General characteristics of the respondents.

\begin{tabular}{|c|c|c|c|c|}
\hline \multirow{2}{*}{$\begin{array}{l}\text { General Characteristics } \\
\text { of the Respondents }\end{array}$} & \multicolumn{3}{|c|}{$\begin{array}{l}\text { Respondents Grouped According to the } \\
\text { Type of Housing }\end{array}$} & \multirow{2}{*}{$p$-Value } \\
\hline & $\begin{array}{c}{[\text { ALL] }} \\
N=\mathbf{1 7 0}\end{array}$ & $\begin{array}{l}\text { House } \\
N=64\end{array}$ & $\begin{array}{l}\text { Apartment } \\
N=106\end{array}$ & \\
\hline \multicolumn{4}{|l|}{ Sex } & \multirow{3}{*}{$0.124^{\mathrm{a}}$} \\
\hline Male & $73(43.2 \%)$ & $32(50.8 \%)$ & $41(38.7 \%)$ & \\
\hline Female & $96(56.8 \%)$ & $31(49.2 \%)$ & $65(61.3 \%)$ & \\
\hline Age, Mean \pm Std. Deviation & $34.86 \pm 10.62$ & $34.04 \pm 11.97$ & $35.35 \pm 9.73$ & $0.188^{b}$ \\
\hline \multicolumn{4}{|l|}{ Age } & \multirow{5}{*}{$0.104^{\mathrm{a}}$} \\
\hline $19-30$ & $57(33.5 \%)$ & $27(42.2 \%)$ & $30(28.3 \%)$ & \\
\hline $31-40$ & $77(45.3 \%)$ & $25(39.1 \%)$ & $52(49.1 \%)$ & \\
\hline $41-50$ & $22(12.9 \%)$ & $5(7.8 \%)$ & $17(16 \%)$ & \\
\hline $51-70$ & $14(8.2 \%)$ & $7(10.9 \%)$ & $7(6.6 \%)$ & \\
\hline \multicolumn{4}{|l|}{ Location of living } & \multirow{3}{*}{$<0.001^{\mathrm{a}}$} \\
\hline Central urban area & $139(81.8 \%)$ & $35(54.7 \%)$ & $104(98.1 \%)$ & \\
\hline Suburb & $31(18.2 \%)$ & $29(45.3 \%)$ & $2(1.9 \%)$ & \\
\hline \multicolumn{4}{|l|}{ Level of education } & \multirow{4}{*}{$0.356^{\mathrm{a}}$} \\
\hline High school & $28(16.5 \%)$ & $12(18.8 \%)$ & $16(15.1 \%)$ & \\
\hline College/Faculty & $97(57.1 \%)$ & $39(60.9 \%)$ & $58(54.7 \%)$ & \\
\hline Master and higher level of education & $45(26.5 \%)$ & $13(20.3 \%)$ & $32(30.2 \%)$ & \\
\hline \multicolumn{4}{|l|}{ Marital status } & \multirow{3}{*}{$0.070^{a}$} \\
\hline Married & $68(40 \%)$ & $20(31.3 \%)$ & $48(45.3 \%)$ & \\
\hline Not married & $102(60 \%)$ & $44(68.8 \%)$ & $58(54.7 \%)$ & \\
\hline \multicolumn{4}{|l|}{ Do you have children? } & \multirow{3}{*}{$0.245^{\mathrm{a}}$} \\
\hline Yes & $68(40 \%)$ & $22(34.4 \%)$ & $46(43.4 \%)$ & \\
\hline No & $102(60 \%)$ & $42(65.6 \%)$ & $60(56.6 \%)$ & \\
\hline \multicolumn{4}{|l|}{ Employment status } & \multirow{6}{*}{0.145} \\
\hline Student & $40(23.5 \%)$ & $20(31.3 \%)$ & $20(18.9 \%)$ & \\
\hline Employed & $121(71.2 \%)$ & $40(62.5 \%)$ & $81(76.4 \%)$ & \\
\hline Unemployed/Retired & $9(5.3 \%)$ & $4(6.3 \%)$ & $5(4.7 \%)$ & \\
\hline Yes & $72(43.1 \%)$ & $23(35.9 \%)$ & $49(47.6 \%)$ & \\
\hline No & $95(56.9 \%)$ & $41(64.1 \%)$ & $54(52.4 \%)$ & \\
\hline
\end{tabular}

a Chi square test, ${ }^{\mathrm{b}}$ Mann-Whitney U Test.

The anonymous questionnaire was carried out in order to evaluate the resilience of the existing housing stock, to point out the key shortcomings of the existing concept of collective residential buildings and to examine the guidelines for its improvement and increase of resilience, which are further proposed through the model.

The survey included respondents aged 19 to 70 years at an average age of $34.86 \pm 10.62$ years. Women were represented by $56.8 \%$ of the sample, while the highest percentage of the respondents (57.1\%) had higher education. There were $37.6 \%$ house 
residents and $62.4 \%$ apartment residents. Most $(81.8 \%)$ were from urban areas, while $18.2 \%$ of respondents were coming from the suburbs. Married respondents consisted of $40 \%$ of the sample, and the same percentage of respondents were the ones with children. Employed people made up the majority of the respondents, $71.2 \%$, while the rest were students $(23.5 \%)$ and pensioners and the unemployed $(5.3 \%)$ (Table 1$)$. The overall structure of the respondents corresponds with the population of Podgorica.

The advantages and disadvantages of living in an apartment and in a house during the pandemic were examined on a five-point Likert-type scale ( $1=$ strongly disagree to $5=$ strongly agree). There are two scales for four items: Disadvantages of living in a residential building and Advantages of living in a house. The scales were created for research purposes and show good reliability (Disadvantages of living in a residential building: Cronbach's Alpha $=0.837$ and Advantages of living in a house: Cronbach's Alpha $=0.803$ ).

To describe the significant parameters depending on the type, in statistical data processing, we used frequencies and percentages, sample average value (arithmetic mean) with the corresponding standard deviation. Relative importance index was calculated. Chi square test and Mann-Whitney test were used to test the differences between the parameters. Examination of the predictive properties of independent variables was tested using multivariate linear regression. The probability level was set at $p \leq 0.05$. Statistical processing and analysis were performed in the statistical package SPSS ver. 24 (Statistical Package for the Social Sciences) for Windows.

The resilient residential model, formed on the basis of sublimated conclusions of previously conducted research, is a complete set of mechanisms whose application to existing residential buildings can, in our view, achieve a significantly higher degree of resilience to current-pandemic as well as future-challenges. As the model advocates for universal values in the domain of the residential concept, we believe that its application can be wider than exclusively local-for the territory of Podgorica and Montenegro in general. In addition, the model can be applied even more simply to future objects by integrating its guidelines into design in order to be initially designed with a significantly higher degree of resilience. The model is further applied to specific residential buildings in Podgorica.

We believe that research conceived in this way, by the combined method, can sufficiently confirm the starting premise of the research, as well as the working definition of a residential building resilient to current and future challenges. The results of the conducted analyses also provide new and significant insights into the limitations of current residential construction concepts; hence, the paper offers possible solutions for overcoming the identified issues.

\section{The Survey Results}

As the user of the residential space is a central figure in this research, the qualitative survey was conducted in order to point out the key shortcomings of the current housing conditions in the context of the COVID-19 restrictions, as well as to examine the guidelines for their improvement and possibly increase their resilience.

The survey results showed that the majority of the respondents $(80.6 \%)$ worked or studied from home during the lockdown. There was a slightly higher number of respondents who worked from home that live in a house $(84.4 \%)$ compared to those who live in an apartment $(78.3 \%)$ but without statistically significant differences. Nearly half of the respondents (43.1\%) stated that they had struggled to organize an adequate working environment within the living space during work or study from home. This percentage is slightly higher when it comes to the respondents living in an apartment $(47.6 \%)$ compared to those living in a house $(35.9 \%)$ but without a statistically significant difference. Vacation properties outside of the city were used as a space for work or study by $24.9 \%$ of the respondents during the pandemic lockdown, while $30.2 \%$ of the respondents responded they would use such space if they owned one. Familiarity with the concept of green roof gardens was expressed by $53.3 \%$ of the respondents. Interestingly, a higher percentage of the respondents living in houses (65.1\%) compared to respondents living in apartments $(46.2 \%)$ are familiar with the concept of green roof gardens, $p<0.05$ (Table 2). 
Table 2. Respondents' management of working and studying activities during COVID-19.

\begin{tabular}{|c|c|c|c|c|}
\hline \multirow{2}{*}{$\begin{array}{l}\text { General Characteristics } \\
\text { of the Respondents }\end{array}$} & \multicolumn{3}{|c|}{ Respondents Grouped According to the Type of Housing } & \multirow{2}{*}{$p$-Value } \\
\hline & {$[\mathrm{ALL}] N=\mathbf{1 7 0}$} & House $N=64$ & Apartment $N=106$ & \\
\hline \multicolumn{4}{|l|}{$\begin{array}{l}\text { Have you been working or studying from home } \\
\text { during isolation? }\end{array}$} & \multirow{3}{*}{$0.332^{\mathrm{a}}$} \\
\hline Yes & $137(80.6 \%)$ & $54(84.4 \%)$ & $83(78.3 \%)$ & \\
\hline No & $33(19.4 \%)$ & $10(15.6 \%)$ & $23(21.7 \%)$ & \\
\hline \multicolumn{4}{|l|}{$\begin{array}{l}\text { Was it a problem for you to organize an adequate } \\
\text { working environment within the living space, for } \\
\text { functional or any other reasons? }\end{array}$} & \multirow[t]{3}{*}{$0.140^{\mathrm{a}}$} \\
\hline Yes & $72(43.1 \%)$ & $23(35.9 \%)$ & $49(47.6 \%)$ & \\
\hline No & $95(56.9 \%)$ & $41(64.1 \%)$ & $54(52.4 \%)$ & \\
\hline \multicolumn{4}{|l|}{$\begin{array}{l}\text { If you own a weekend home outside of the city, have } \\
\text { you used it for longer period in the times of } \\
\text { COVID-19 isolation, while working remotely? }\end{array}$} & \multirow{5}{*}{$0.429^{\mathrm{a}}$} \\
\hline Yes & $42(24.9 \%)$ & $16(25 \%)$ & $26(24.8 \%)$ & \\
\hline No & $30(17.8 \%)$ & $14(21.9 \%)$ & $16(15.2 \%)$ & \\
\hline I don't own a weekend home & $46(27.2 \%)$ & $19(29.7 \%)$ & $27(25.7 \%)$ & \\
\hline $\begin{array}{c}\text { I don't own a weekend home, but if I did, I would } \\
\text { have used that opportunity very often }\end{array}$ & $51(30.2 \%)$ & $15(23.4 \%)$ & $36(34.3 \%)$ & \\
\hline \multicolumn{4}{|l|}{$\begin{array}{l}\text { Are you familiar with the current concept of the } \\
\text { green roof gardens as new spaces for social activities } \\
\text { or even active urban agriculture? }\end{array}$} & \multirow[t]{3}{*}{$0.018^{\mathrm{a}}$} \\
\hline Yes & $89(53.3 \%)$ & $41(65.1 \%)$ & $48(46.2 \%)$ & \\
\hline No & $78(46.7 \%)$ & $22(34.9 \%)$ & $56(53.8 \%)$ & \\
\hline
\end{tabular}

The satisfaction of living in an apartment in a residential building during the COVID-19 pandemic lockdown is moderate $(3.22 \pm 1.02)$. The respondents are most dissatisfied with the lack of contact with nature- the lack of a garden or yard $(\mathrm{RII}=0.434)$ and the lack of the possibility of staying outdoors during curfew, i.e., the feeling of being trapped in the apartment $(\mathrm{RII}=0.434)$. They were least bothered by the impossibility of self-isolation in the common areas of the building - entrance, hallways, and elevator $(\mathrm{RII}=0.340)$. The respondents who stayed in a house during the lockdown show much higher overall satisfaction with life in the house $(3.93 \pm 1.05)$. These respondents show the greatest satisfaction with having contact with nature $(\mathrm{RII}=0.311)$ as well as the possibility of staying outdoors during curfew $($ RII $=0.303)($ Table 3$)$.

With a set of categorical questions, we examined the opinions and habits of the respondents that are related to the culture of living in the COVID-19 pandemic lockdown. We also tested whether the respondents who live in an apartment and in a house have similar habits.

When it comes to habits that the respondents kept following the lockdown period, close to half of the respondents $(48.8 \%)$ have still occasionally worked from home. The transition to electronic bill payment was retained by $44.1 \%$ of respondents, while $44.7 \%$ stated that the overall level of digitalization of services is higher at the household level. The lowest percentage of respondents (24.1\%) switched to online shopping. Since the COVID-19 pandemic curfew, as many as $75.9 \%$ of respondents spend more time in nature or plan to do so. More frequent weekend "out of town" trips were recorded with $50.6 \%$, of the respondents, $9.4 \%$ of the respondents decided to buy land for the construction of a vacation property outside the city, $6.5 \%$ decided to buy land for agricultural purposes, while $5.9 \%$ decided to buy real estate outside the city. The decision to buy land to build a house outside the city 
was made by $10.6 \%$ of respondents, as expected, a higher percentage among those living in an apartment $(15.1 \%), p<0.05$.

Table 3. Advantages and disadvantages of different types of housing in COVID-19 pandemic.

\begin{tabular}{ccc}
\hline & $\begin{array}{c}\text { Mean } \pm \text { Std. Deviation } \\
\text { (Minimum-Maximum) }\end{array}$ & Relative Importance Index \\
\hline Disadvantages of living in a residential building_Total Score & $3.22 \pm 1.02(1-5)$ & 0.434 \\
\hline Lack of contact with nature due to not having a garden or a yard & $3.48 \pm 1.20(1-5)$ & 0.340 \\
\hline $\begin{array}{c}\text { Impossibility of isolation in common building areas: } \\
\text { entrance hallway, corridors, elevators }\end{array}$ & $2.73 \pm 1.23(1-5)$ & 0.434 \\
\hline $\begin{array}{c}\text { No possibility of being (spending time) outside during the } \\
\text { lockdown, i.e., the feeling of being trapped in the apartment }\end{array}$ & $3.48 \pm 1.27(1-5)$ & 0.398 \\
\hline $\begin{array}{c}\text { No possibility of physical activities (outside) during the lockdown } \\
\text { Advantages of living in a house-one-family housing_Total Score }\end{array}$ & $3.20 \pm 1.32(1-5)$ & $3.93 \pm 1.05(1-5)$ \\
\hline $\begin{array}{c}\text { Contact with nature due to having a garden or a yard } \\
\text { Higher level of security and protection due to isolation of the } \\
\text { neighbors (not sharing common areas as if in a building) }\end{array}$ & $4.14 \pm 1.13(1-5)$ & 0.311 \\
\hline $\begin{array}{c}\text { Possibility of being (spending time) outside during the lockdown } \\
\text { Possibility of physical activities (outside) during the lockdown }\end{array}$ & $4.03 \pm 1.34(1-5)$ & 0.283 \\
\hline
\end{tabular}

Half of the respondents living in apartment buildings stated that it would suit them to have green roof gardens $(51 \%)$ in the current pandemic period but also in post-pandemic conditions; $20.2 \%$ of the respondents would use this space for friends gathering, while $4.8 \%$ of the respondents would use this space for urban agriculture; $16.3 \%$ of the respondents would not use this space or would not consider it important, while $7.7 \%$ of the respondents are not familiar with this concept. In the current pandemic period and in post-pandemic conditions, $74.3 \%$ of the respondents living in apartment buildings would use common terraces. For $18.1 \%$ of the respondents, it would not be important if the apartment was designed as flexible; the rest $(81.9 \%)$ find that this option would be useful.

As many as $96.4 \%$ of all the respondents consider it significant to have the possibility to significantly adapt the apartment to their personal needs, in coordination with the architect of the building, before buying an apartment in an residential building under development (Table 4).

If they could choose, $69.6 \%$ of the respondents would live in a house, $26.2 \%$ in an apartment in a residential building that has green roof gardens and $4.2 \%$ in an apartment in a residential building that does not have to have a roof garden. Of the total number of those already living in a house, $98.4 \%$ would still choose a house as a living space, while, of the total number of those living in an apartment, half $(52.4 \%)$ would choose a house. This difference is also statistically significant $(p<0.001)$.

We used multiple linear regression to examine the conditions of the satisfaction of living in an apartment or in a house during the pandemic. The statistically significant predictors of satisfaction with living in an apartment were: gender (Beta $=-0.225$, CI: $-0.889--0.072, p<0.05)$, work/study from home during the lockdown (Beta $=0.381$, CI: $0.489-1,458, p<0.001)$, familiarity with the current concept of green roof gardens (Beta $=0.208, C I: 0.035-0.832, p<0.05)$. In other words, women notice greater disadvantages of living in an apartment during the pandemic, as well as those who worked or studied from home during the lockdown and those familiar with the concept of green roof gardens (Table 5). No statistically significant predictor of satisfaction was detected for living in a house during the COVID-19 pandemic. 
Table 4. Respondents' attitudes towards green roof gardens.

\begin{tabular}{|c|c|c|c|c|}
\hline & \multicolumn{3}{|c|}{$\begin{array}{l}\text { Respondents Grouped According to } \\
\text { the Type of Housing }\end{array}$} & \multirow{2}{*}{$p$-Value } \\
\hline & $\begin{array}{c}{[\text { ALL] }} \\
N=170\end{array}$ & $\begin{array}{l}\text { House } \\
N=64\end{array}$ & $\begin{array}{l}\text { Apartment } \\
N=106\end{array}$ & \\
\hline \multicolumn{5}{|l|}{ Have you kept your habits from period of isolation and active pandemic measures, even after? } \\
\hline Occasional remote work from home & $83(48.8 \%)$ & $33(51.6 \%)$ & $50(47.2 \%)$ & 0.579 \\
\hline Online shopping & $41(24.1 \%)$ & $18(28.1 \%)$ & $23(21.7 \%)$ & 0.343 \\
\hline E-payment of household bills & $75(44.1 \%)$ & $26(40.6 \%)$ & $49(46.2 \%)$ & 0.476 \\
\hline Higher level of digitalization of services in household, in general & $76(44.7 \%)$ & $28(43.8 \%)$ & $48(45.3 \%)$ & 0.846 \\
\hline \multicolumn{5}{|l|}{ After lockdown during the pandemic, have you been practicing or planning to practice: * } \\
\hline Spending time in nature, more often & $129(75.9 \%)$ & $51(79.7 \%)$ & $78(73.6 \%)$ & 0.368 \\
\hline Spending weekend outside of the city, more often & $86(50.6 \%)$ & $31(48.4 \%)$ & $55(51.9 \%)$ & 0.663 \\
\hline Buying property-weekend house or cottage outside of the city & $10(5.9 \%)$ & $1(1.6 \%)$ & $9(8.5 \%)$ & 0.063 \\
\hline Buying land to build a house outside of the city & $18(10.6 \%)$ & $2(3.1 \%)$ & $16(15.1 \%)$ & 0.014 \\
\hline Buying land to build a weekend house outside of the city & $16(9.4 \%)$ & $5(7.8 \%)$ & $11(10.4 \%)$ & 0.579 \\
\hline Buying land for agricultural purposes & $11(6.5 \%)$ & $2(3.1 \%)$ & $9(8.5 \%)$ & 0.168 \\
\hline \multicolumn{5}{|l|}{$\begin{array}{l}\text { Would it be convenient for you that your residential building, in the times od active } \\
\text { pandemic, but also in post-pandemic period, has green roof gardens? }\end{array}$} \\
\hline Yes, I would use that kind of space very often & $53(51 \%)$ & - & $53(51 \%)$ & \\
\hline Yes, I would gladly use a green roof garden for gatherings with friends & $21(20.2 \%)$ & - & $21(20.2 \%)$ & \\
\hline Yes, I would gladly use a green roof garden for urban agriculture & $5(4.8 \%)$ & - & $5(4.8 \%)$ & \\
\hline $\begin{array}{l}\text { I'm familiar with green roofs being current, global, trend, but I believe I would not spend } \\
\text { much time there }\end{array}$ & $12(11.5 \%)$ & - & $12(11.5 \%)$ & \\
\hline Existence of that kind of space would not be of big importance for me & $5(4.8 \%)$ & - & $5(4.8 \%)$ & \\
\hline I'm not familiar with the concept of green roof gardens & $8(7.7 \%)$ & - & $8(7.7 \%)$ & \\
\hline \multicolumn{4}{|l|}{$\begin{array}{l}\text { Would it be convenient and important for you that your residential building, in the times } \\
\text { od active pandemic, but also in post-pandemic period, has common terrace areas? }\end{array}$} & \multirow{3}{*}{ - } \\
\hline Yes, I would gladly use a green roof garden for gatherings with friends in smaller groups & $78(74.3 \%)$ & - & $78(74.3 \%)$ & \\
\hline Existence of that kind of space would not be of big importance for me & $27(25.7 \%)$ & - & $27(25.7 \%)$ & \\
\hline \multicolumn{4}{|l|}{$\begin{array}{l}\text { Would it be convenient and important for you, in the times od active pandemic, but also in } \\
\text { post-pandemic period, that your apartment is designed as flexible and adaptable? }\end{array}$} & \multirow{4}{*}{ - } \\
\hline $\begin{array}{l}\text { Yes, it would be of importance for me, as I would use that opportunity in order to increase } \\
\text { or decrease some of the spaces/rooms in the apartment }\end{array}$ & $52(49.5 \%)$ & - & $52(49.5 \%)$ & \\
\hline $\begin{array}{l}\text { Yes, it would be of importance for me, in order to organize a working area/space in } \\
\text { the apartment }\end{array}$ & $34(32.4 \%)$ & - & $34(32.4 \%)$ & \\
\hline $\begin{array}{l}\text { It wouldn't be of great importance for me; I don't believe I would use that } \\
\text { opportunity much }\end{array}$ & $19(18.1 \%)$ & - & $19(18.1 \%)$ & \\
\hline \multicolumn{4}{|l|}{$\begin{array}{l}\text { Would it be convenient and important for you that, prior to buying an apartment (in } \\
\text { construction), you can alter and adapt it according to your own needs, in coordination with } \\
\text { the architect who designed it? }\end{array}$} & \multirow{3}{*}{0.053} \\
\hline $\begin{array}{l}\text { Yes, it would be important for me as I would use that opportunity to change and adapt the } \\
\text { living space according to my needs, with professional help }\end{array}$ & $159(96.4 \%)$ & $62(100 \%)$ & $97(94.2 \%)$ & \\
\hline $\begin{array}{l}\text { It would not be of great importance for me as I am only interested in the square footage of } \\
\text { the apartment and the number of rooms }\end{array}$ & $6(3.6 \%)$ & $0(0 \%)$ & $6(5.8 \%)$ & \\
\hline \multicolumn{4}{|l|}{$\begin{array}{l}\text { What type of living space you choose in the times of active pandemic, but also in } \\
\text { post-pandemic period: }\end{array}$} & \multirow{4}{*}{$<0.001$} \\
\hline House-one-family housing & $117(69.6 \%)$ & $62(98.4 \%)$ & $55(52.4 \%)$ & \\
\hline The apartment in the residential building with green roof garden & $44(26.2 \%)$ & $1(1.6 \%)$ & $43(41 \%)$ & \\
\hline The apartment in the residential building that does not necessarily have green roof garden & $7(4.2 \%)$ & $0(0 \%)$ & $7(6.7 \%)$ & \\
\hline
\end{tabular}

* Multiple questions. Chi square test was performed. 
Table 5. Predictors of housing satisfaction in the pandemic.

\begin{tabular}{|c|c|c|c|c|c|c|c|c|}
\hline & \multicolumn{4}{|c|}{$\begin{array}{l}\text { Disadvantages of Living in the } \\
\text { Apartment during COVID-19 Pandemic }\end{array}$} & \multicolumn{4}{|c|}{$\begin{array}{l}\text { Advantages of Living in One-Family } \\
\text { House during COVID-19 Pandemic }\end{array}$} \\
\hline & \multirow{2}{*}{$\begin{array}{l}\text { Standardized } \\
\text { Coefficients } \\
\text { Beta }\end{array}$} & \multirow[t]{2}{*}{$p$} & \multicolumn{2}{|c|}{$\begin{array}{c}95.0 \% \\
\text { Confidence } \\
\text { Interval for B }\end{array}$} & \multirow{2}{*}{$\begin{array}{l}\text { Standardized } \\
\text { Coefficients } \\
\text { Beta }\end{array}$} & \multirow[t]{2}{*}{$p$} & \multicolumn{2}{|c|}{$\begin{array}{c}95.0 \% \\
\text { Confidence } \\
\text { Interval for B }\end{array}$} \\
\hline & & & $\begin{array}{l}\text { Lower } \\
\text { Bound }\end{array}$ & $\begin{array}{l}\text { Upper } \\
\text { Bound }\end{array}$ & & & $\begin{array}{l}\text { Lower } \\
\text { Bound }\end{array}$ & $\begin{array}{l}\text { Upper } \\
\text { Bound }\end{array}$ \\
\hline (Constant) & & 0.116 & -0.485 & 4.336 & & 0.000 & 3.566 & 6.819 \\
\hline Age & 0.001 & 0.996 & -0.028 & 0.028 & -0.170 & 0.308 & -0.047 & 0.015 \\
\hline Sex & -0.225 & 0.022 & -0.889 & -0.072 & -0.065 & 0.612 & -0.678 & 0.403 \\
\hline Living location & 0.034 & 0.734 & -1.726 & 2.442 & -0.234 & 0.081 & -1.050 & 0.064 \\
\hline Level of education & -0.059 & 0.570 & -0.754 & 0.417 & -0.192 & 0.174 & -1.294 & 0.240 \\
\hline Marital status & 0.128 & 0.469 & -0.465 & 1.002 & 0.448 & 0.191 & -0.526 & 2.567 \\
\hline Having children & -0.169 & 0.335 & -1.081 & 0.372 & -0.602 & 0.095 & -2.914 & 0.242 \\
\hline Employment status & -0.060 & 0.604 & -0.711 & 0.416 & 0.062 & 0.722 & -0.619 & 0.886 \\
\hline Working/studying from home during the isolation & 0.381 & $<0.001$ & 0.489 & 1.458 & 0.061 & 0.692 & -0.743 & 1.110 \\
\hline $\begin{array}{l}\text { Problem of organizing an adequate working } \\
\text { environment within the living space }\end{array}$ & 0.095 & 0.308 & -0.185 & 0.579 & -0.008 & 0.959 & -0.686 & 0.652 \\
\hline Use of weekend house due to COVID-19 pandemic & 0.097 & 0.299 & -0.059 & 0.191 & -0.128 & 0.319 & -0.261 & 0.087 \\
\hline Familiarity with the current concept of green roof gardens & 0.208 & 0.033 & 0.035 & 0.832 & -0.102 & 0.494 & -0.879 & 0.430 \\
\hline
\end{tabular}

Note: Age: numeric, Sex: $0=$ female, $1=$ male, Living location: $0=$ suburbs, $1=$ central urban area, Level of education: $0=$ college $/$ faculty + master and higher level of education, $1=$ high school, Marital status: $0=$ not married, $1=$ married, Do you have children: $0=$ no, $1=$ yes, Employment status: $0=$ employed, $1=$ unemployed Working/studying from home during the isolation: $0=$ no, $1=$ yes, Problem of organizing an adequate working environment within the living space: $0=$ no, $1=$ yes, Use of weekend house due to COVID-19 pandemic: $0=$ no, $1=$ yes; Familiarity with the current concept of green roof gardens: $0=$ no, $1=$ yes.

Dependent variables: Disadvantages of living in the apartment during COVID-19 pandemic: numeric, Advantages of living in one-family house during the COVID-19 pandemic.

\section{Quantitative Survey Conclusions}

The survey aimed to determine how the users of residential space in Podgorica evaluate current housing conditions, and if their perception corresponds to the starting premise of this research. The results of the survey show that nearly half of the respondents have struggled to organize an adequate working environment within the living space during work or study from home. The satisfaction of living in an apartment in a residential building during the COVID-19 lockdown is moderate, and the main disadvantages are the lack of contact with nature- the lack of a garden or a yard, as well as the possibility of staying outdoors during curfew. These are the main reasons why the existence of a rooftop garden would be appreciated. Interestingly, the respondents were least bothered by the impossibility of self-isolation in the common areas of the building, which shows that people tend to highly value freedom of organization, possibility of social activities and time spent outdoors, possibly in nature. Another possibility that would be highly appreciated is the ability to participate in the creation of their apartment unit layout, indicating interest in practicing the right to adequate residential space.

\section{Defining a Model for Achieving Residential Resilience}

\subsection{Values in the Domain of Housing in the Context of COVID-19, and Model Formation}

In the time of COVID-19, housing occupies a central role in the realization of life activities, both basic and work-related obligations. Although research on effective housing strategies and concepts that can adequately respond to the current pandemic is increasingly relevant in academia, the related state policies remain insufficiently engaged. However, this is understandable to some extent considering that various challenges are rapidly 
altering and the nature of each new disturbance is different. This leads to the conclusion that it is necessary to find a solution that suits the current pandemic and a wider range of potential challenges in the future.

The current pandemic caused by the COVID-19 virus primarily threatens physical health, so the first level of crisis we are facing is certainly the one of public health. From this, it would logically follow that the model should deal with improving conditions in the context of a healthier residential environment by providing adequate lighting and ventilation, natural ventilation of common areas in the building and vertical communications and appropriate cubature of spaces of longer stay in order to create a healthy and safe environment [2,46-48]. However, the paper does not deal with these expected aspects of housing improvement in more detail as, in addition to the fact that there is extensive research on these topics, it is indicative that respondents of the survey find that these characteristics of space, in terms of risk, are less disturbing long-term. On the other hand, numerous restrictions on outdoor and social activities, leading to social isolation, are highly associated with risks of anxiety, depression and even premature mortality $[49,50]$. Therefore, we consider a "new normal" in terms of the realization of everyday life, including social activities and contact with nature, to be more important in terms of overall wellbeing-physical, mental and social health. The ambition of this research is to offer a model for achieving resilience of a residential building through improvement in the context of creating adequate space for the smooth realization of daily life activities in times of pandemic challenges and constraints, thus creating an adequate physical framework vital to the social, mental and physical health of its users.

Based on the sublimated conclusions from the previous sections, the confirmed starting premise of the research by the results of the questionnaire and the working definition of a residential building resilient to challenges, a model was formulated to achieve residential resilience of buildings and residential areas to the COVID-19 pandemic scenario, with the goal of their transformation or initial design in the direction of a healthier and more adequate living environment. The model represents a set of measures and guidelines, representing values in housing (Table 6) whose integral application we believe could achieve long-term resilience to both current and future challenges, restrictions and special conditions to which multi-family residential space will inevitably be exposed. The model of residential resilience functions as an open system. By applying it to existing or future buildings, we believe that it would enable their smooth functioning in the conditions of the current pandemic.

Table 6. Model for achieving residential resilience with proposed measures M1-M5.

\begin{tabular}{ccc}
\hline M & Measure/Mechanism & Description \\
\hline M1 & Flexible apartment layout & $\begin{array}{c}\text { Creating possibilities for functional reorganization of the apartment layout in } \\
\text { order to create working space (or space for isolation) if or when needed. }\end{array}$ \\
\hline M2 & $\begin{array}{c}\text { Open and closed spaces for gatherings } \\
\text { and social interaction within a building }\end{array}$ & $\begin{array}{c}\text { Creating open and closed (outdoor and indoor) spaces for } \\
\text { gatherings - common and semi-private, extended "living rooms" } \\
\text { for social activities. }\end{array}$ \\
\hline M3 & $\begin{array}{c}\text { Green gardens-activation and } \\
\text { landscaping of flat roofs and vertical } \\
\text { surfaces within a building }\end{array}$ & $\begin{array}{c}\text { Introducing green gardens, through landscaping of the flat roof and/or } \\
\text { adequate vertical façade surfaces, in order to enable immediate contact with } \\
\text { nature and to create conditions for activation of urban agriculture. }\end{array}$ \\
\hline M4 & $\begin{array}{c}\text { Immediate contact with nature within } \\
\text { every apartment }\end{array}$ & $\begin{array}{c}\text { Bringing nature in: enabling contact with nature within every apartment unit } \\
\text { by planting greens on the loggias and terraces. }\end{array}$ \\
\hline M5 & $\begin{array}{c}\text { Activation of inner yards of compact } \\
\text { urban blocks }\end{array}$ & $\begin{array}{c}\text { Converting inner yards to places for social activities, in cases of } \\
\text { compact urban tissue, by cultivating existing green surfaces on the ground or } \\
\text { adding prefabricated, connecting structures between buildings } \\
\text { on upper floors. }\end{array}$ \\
\hline
\end{tabular}


Measure M1 addresses the imperative of flexible and adaptable apartment unit layout in general and in the specific conditions of the pandemic [22,25-28] due to the need to reorganize the living space according to the changed spatial needs-in order to organize a separate, isolated working area in the apartment or to eventually isolate a family member due to virus contagion. M2 focuses on the importance of creating indoor and outdoor common spaces for social activities within the building [22], which act as extended "living rooms", enabling gatherings in smaller groups, and representing "new normal" social venues as a replacement for the pre-COVID ones. M3 promotes immediate contact with nature within the building $[2,24]$ by activating and landscaping flat roofs and/or adequate vertical façade surfaces and converting them to urban gardens [51,52]. This could be done on the level of every apartment unit, to a lesser extent, through greening of loggias, terraces and balconies, as proposed in M4. M5 presents complementary measures, dealing with activation of the inner yard of compact urban blocks by cultivating and landscaping inner courtyard areas or, if necessary, adding prefabricated, connecting structures between buildings on upper floors. The application of this guideline is not obligatory if such spaces could be created in any other way, as proposed in M2-M4.

The integral application of these measures additionally achieves a certain autonomy of a multi-family residential building as it becomes a complete system that provides its users with adequate living space and the space for working remotely, as well as important complementary content-engaging environments for leisure and social activities in smaller groups. We believe this sufficiently overcomes the limitations of multi-apartment buildings in the COVID-19 period, as well as their lesser attractiveness compared to the functional comfort provided by a single-family building, while preserving the mental, social and physical health of the residents. The individual mechanisms and measures proposed by the model are not necessarily novel in the context of environmental resilience to the pandemic. However, the contribution of this paper and the model is that it forms a strategically selected and carefully grouped set of mechanisms whose combined application to buildings would lead to significant improvements in the quality of the living environment and, consequently, user satisfaction in restrictive living conditions but also in general. Due to the character of the values in housing proposed in the model, we could expect it to be of significance outside of the territorial framework of this research as well.

Although the model was initially set up to be applied to the existing housing stock, its application to future buildings, in the same form, is significantly simpler in the planning and design phase.

In the segment related to setting the theoretical framework of research, we dealt with the topic of flexibility and adaptability of architectural work in general but also of the residential space as qualitative characteristics, which, in the context of resilience, have a significant role in terms of user satisfaction. Namely, research shows that satisfaction with the immediate living environment gradually decreases over time due to changes in the spatial needs of the occupants. It is possible to regain it by changing the physical characteristics of an apartment-by creating a more adaptable and flexible layout [53]. However, the area of the apartment unit could present a challenging circumstance in the case of a studio or very small one-bedroom apartment regarding its flexibility and limited number of options for reorganizing the available living space. The housing concept, in the context of resilience, can be broadly classified into "open concept", "flexible housing", "adaptable housing" and "incremental housing" [54]. The model refers to the first three characteristics of space, while the latter concept today often refers to a proactive urban strategy for less developed, low-income areas of the Third World $[55,56]$.

In addition to this value of the housing concept, the model advocates intensifying residents' contact with nature, which is undoubtedly important for mental and physical health, especially in times of pandemic constraints. The definite importance of this environmental quality in the pandemic is emphasized by the unequivocal results of the survey as respondents emphasized the lack of contact with nature as a key drawback of restrictions on leaving the residence. 
The greening of public and semi-public areas, i.e., their activation through landscaping and the formation of green gardens, and their potential use as a space for practicing urban agriculture on horizontal or vertical surfaces, is an increasing global trend in recent decades [57], enhancing community participation [58] and improving public health [59]. There are various models of these interventions, the most common of which is the community garden [60] in abandoned or unused urban locations or suburbs. As the research deals with increasing the degree of resilience of multi-family residential buildings, the guidelines suggest intensifying contact with nature at the level of the building itself. This can be achieved through landscaping of flat roofs or accessible vertical surfaces, but symbolic contact with nature can be achieved within every apartment with a terrace or loggia, especially if they are initially equipped with jardinières or the design provides that possibility.

Such nature-based solutions (NBS) simultaneously result in environmental, social and economic benefits and contribute to building community resilience [51,61]. In the case of activating the space for urban agriculture, there are many more socio-cultural benefits related to public health and social and individual well-being, environmental education, user participation in the development of their urban environment and thus strengthening the sense of community [62], inclusion, local social and cultural identity [63] and community commitment [64]. Strategic planning of such a productive urban landscape, which can significantly change the current lifestyle and spending of free time, is one of the measures to achieve a sustainable, resilient, livable and healthy city $[65,66]$, which is of great importance today during the pandemic in order to achieve healthy and quality urban living.

In the context of this paper and restrictions imposed by COVID-19, multi-purpose urban gardens on flat roofs are perceived as places for social interaction and spending time outdoors and in "nature" [51] while possibly engaging in urban agriculture [67,68], potential spaces for organizing occasional remote work environments, spaces that encourage participation of residents in the life of the community and in changing their immediate environment, which can significantly contribute to reducing alienation and loneliness. All of the above unequivocally contributes to the creation of an adequate framework for a healthier urban everyday life, increasing the residential resilience to pandemic circumstances and, consequently, increasing the resilience of residents and the community to the challenges they face during COVID-19.

\subsection{Application of the Model: Case of Blok 5 Residential Buildings C1 and C2}

In order to test the proposed model for achieving residential resilience, we will apply it to the selected buildings of Blok 5, a residential area in Podgorica. The choice of the buildings is not accidental: the concept of this residential block is, to a certain extent, close to the theoretical concept that this paper advocates for. Blok 5 (1977-1984), by architect Mileta Bojović, represents the realization of the first prize-winning design in an international architectural competition in 1977, done according to the already adopted detailed urban plan from 1975 (Figure 2). This residential area consists of thirteen buildings of three types-five skyscrapers, two buildings with towers and six elongated buildings-in a total of 1800 apartments. It is equipped with social standard facilities-health center, nursery, kindergarten and primary school—and is characterized by spacious green areas between buildings, characteristic of urban plans in socialism.

The distinguishing quality of this design relates to the emphasized flexibility of the buildings. The first level of flexibility concerns the structure of apartment types, which allowed the Investor (SIZ-Self-managing Interest Community) to adjust the structure of the required residential units from a studio to a four-room apartment within the same volumes of the buildings. The second level of greater importance for this research, relates to the possibility of changing and adapting the apartment units according to the needs of their end-users. Taking the participation of an individual in creating one's own space as a key need, the architect enabled the project to offer a large number of apartment variants of the same elements within the same square footage and within the norms for social housing 
but with a considerate modular organization. The project also foresaw the adaptability of the facade: loggias and non-constructive facades could be replaced and glazed over time.
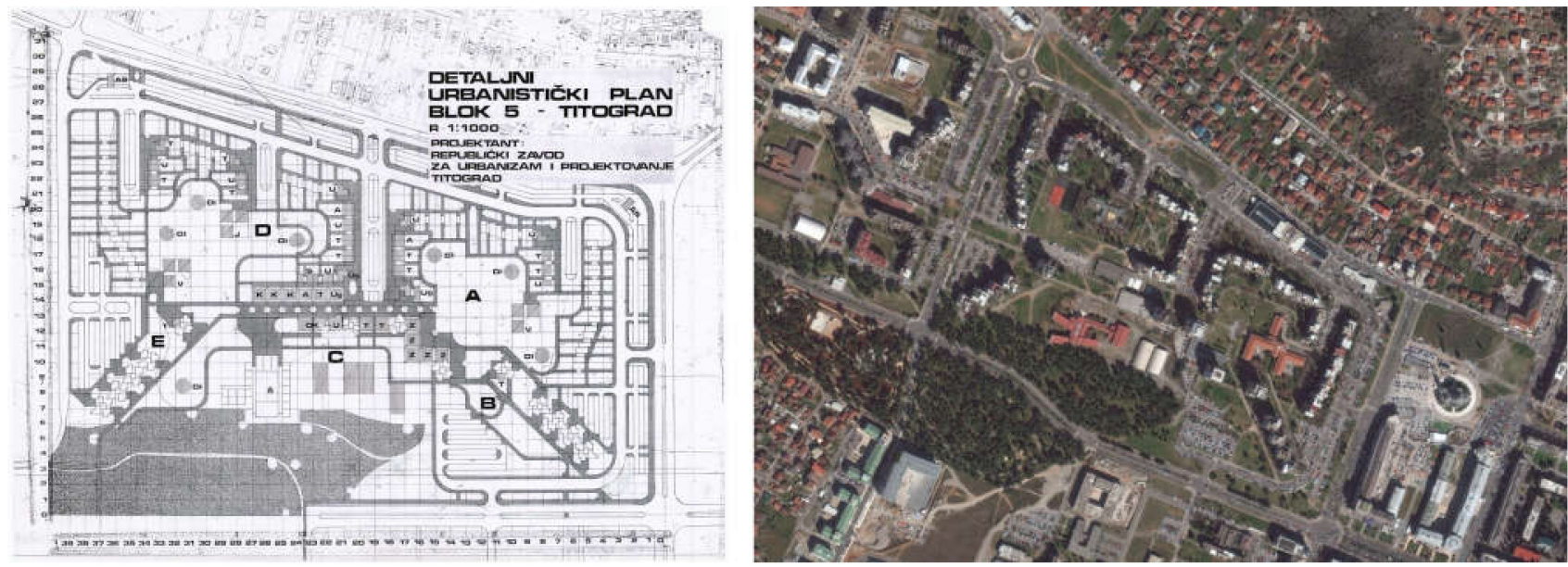

Figure 2. Detailed urban plan of Blok 5 (1975), Podgorica on the left, and a map showing this residential area with large green surfaces on the right.

In order for the end users to be able to adjust the interior of their apartments to their own needs, habits and desires, the residential units were designed in a way so that only the core of the apartment, including the plumbing system, was fixed, while all other partition walls were movable; they could be unscrewed, relocated or completely removed. Many possible solutions were envisaged by the project, and the architect was available to future users in order to design their living space as adequately as possible in advance-during the design phase and after the construction of Blok 5. In addition, the emphasized dynamic of the volumes of the buildings enabled the formation of a large number of terraces for regular use and for greening while the loggias came equipped with concrete jardinières. The apartments in two of the six elongated buildings of the block have a front garden, which we consider an exceptional quality of a residential space in a multi-family building located in the urban fabric, especially nowadays during the pandemic. The roofs of all the buildings are flat, and the buildings had common spaces for socialization: in some cases, indoor spaces on ground floors and open terraces on the higher levels.

This brief review of the basic characteristics of Blok 5 clarifies the choice of the buildings in this residential block for the model verification and creates a precondition for the application of the proposed guidelines. However, in the years of the transition, precisely because of the concept of flexibility at the building level and disjointed volumes, the space of this area was significantly degraded, and the advantages of the project turned into their opposites to a large extent. The common spaces for socialization were privatized by the tenants and converted into residential space, which has also happened to a lesser extent with the common terraces on the flat roofs of the buildings. Many of the front gardens of apartments on the ground floor have suffered a similar fate; they were walled up and turned into additional residential space.

For the needs of this research, we choose the high-rises C1 and C2 (Figure 3), centrally positioned in the residential area, physically connected on the ground level with the health center facility. Both high-rises have 16 floors and a total of 64 residential units per buildingfour apartments per floor. The structural elements of the buildings are reinforced concrete canvases, and the basic design module is $6 \times 6 \mathrm{~m}$. The vertical communications are adequately dimensioned; each high-rise is equipped with three elevators and an open, fully ventilated staircase. 


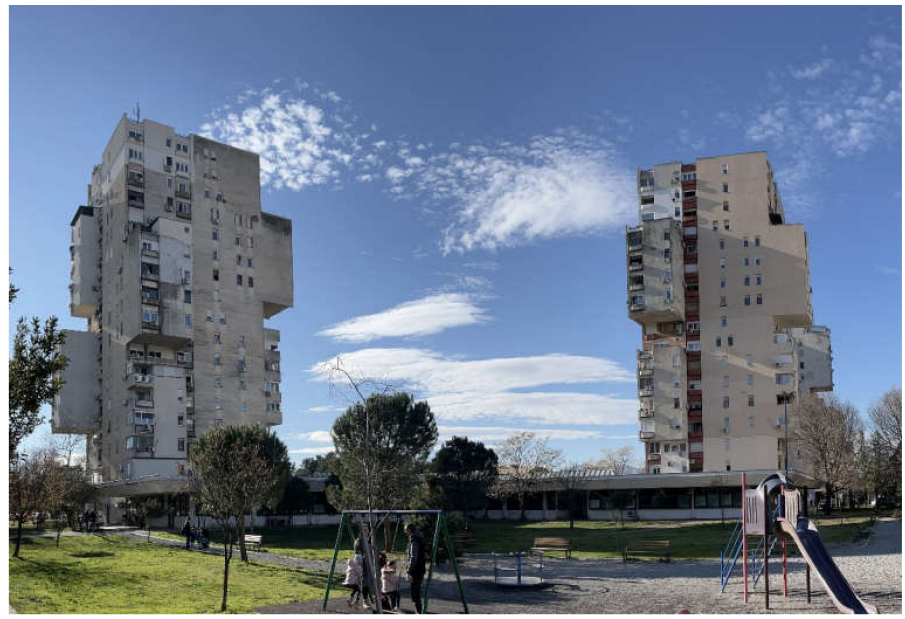

Figure 3. Sixteen-story high-rise buildings $\mathrm{C} 1$ and $\mathrm{C} 2$, connected on the ground level with health center facility.

On the basis of this brief review of the elementary characteristics of the selected buildings, we further present the application of the model and its measures as follows:

Application of M1: Application of the model's M1 guideline to the C1 and C2 highrises is possible to a large extent. An example of a typical floor (Figure 4) shows that the apartments have a free, open plan and that only the plumbing system is fixed-kitchen and bathroom. All other partitions in the apartment can be disassembled, which enables their removal or relocation in order to create a new functional organization of space due to changes in family structure or changes related to the temporary organization of working or isolation area in the apartment. The limiting factor can be the number or the surface of openings on the facade.

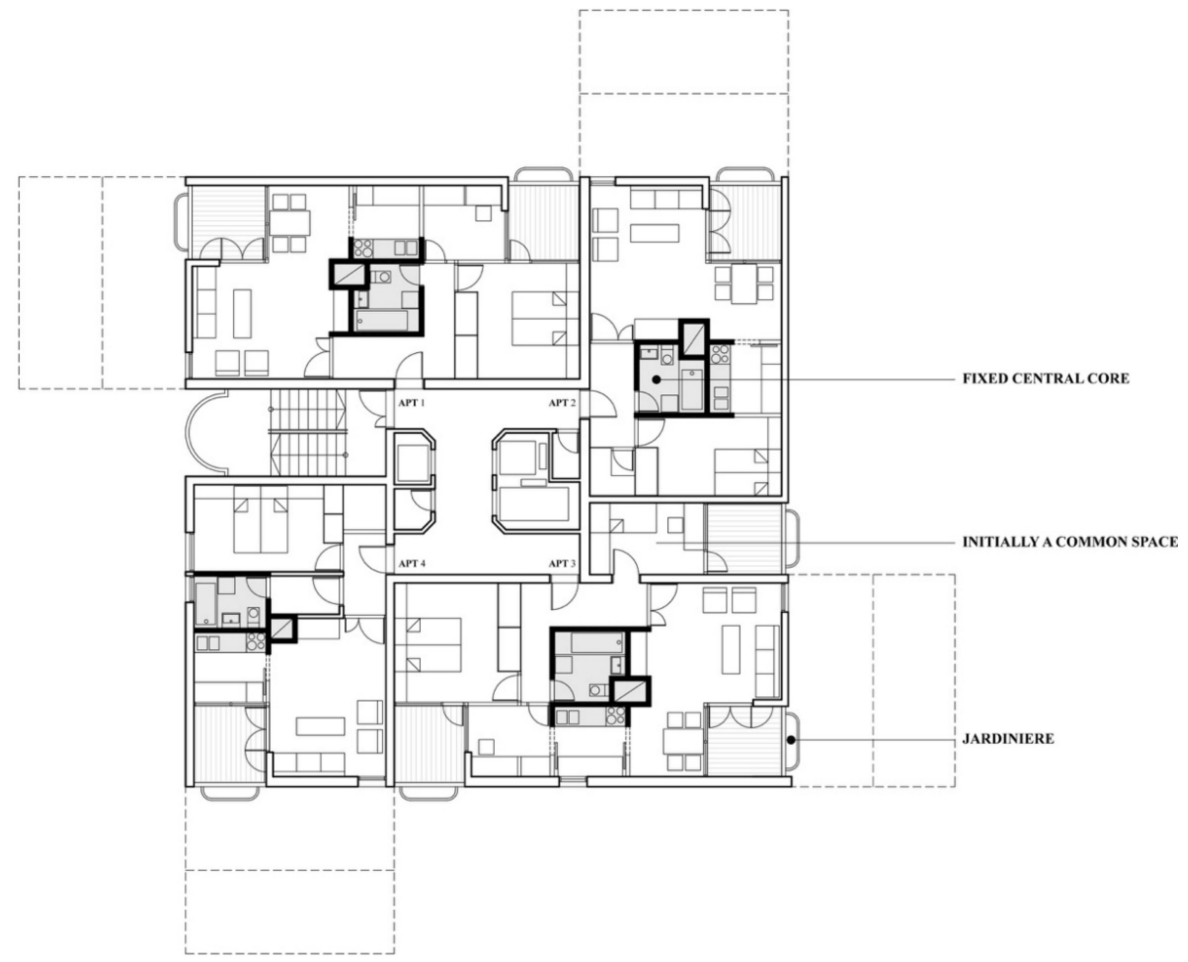

Figure 4. Typical floor plan of levels 1-4 of the high-rises $C 1$ and $C 2$, with smaller units-studio and one-bedroom apartments, showing flexibility of the layout, with central core fixed (bathroom and kitchen), and round circulation enabled. Initially designed common space of every fourth floor marked, converted into residential space (a bedroom with loggia). 
Application of M2: Realization of indoor and outdoor spaces for gathering and social interaction within a building, especially during the pandemic, in the case of C1 and C2 would require removal of added residential upgrades, i.e., return of the building to its original condition. In that case, initially designed open spaces, terraces on every fourth floor (Figure 4), could be used for the purpose of celebrating children's birthdays, playdates, gatherings in general, in smaller groups. A less drastic intervention would be achieving this type of space on the unused flat roof of the building.

Application of M3: Greening of flat roofs of buildings for the whole Blok 5 residential area would be an important intervention since the total area is close to 15 thousand square meters. Converting flat roofs of the $\mathrm{C} 1$ and $\mathrm{C} 2$ high-rises into a horizontal urban garden is exclusively a technical issue as the roofs of the buildings are passable and have a concrete parapet of adequate height for security reasons. All residents have access to the roof. The favorable specificity of these two buildings is the existence of a flat, inactivated surface at the level of the first floor, which is the roof of the health center, with an area of about $1000 \mathrm{~m}^{2}$ (Figure 5). This platform is accessible via stairs. This space is highly adequate for providing conditions for the implementation of urban agriculture, and its activation would provide a very attractive and unique urban space in Podgorica and Montenegro in general.

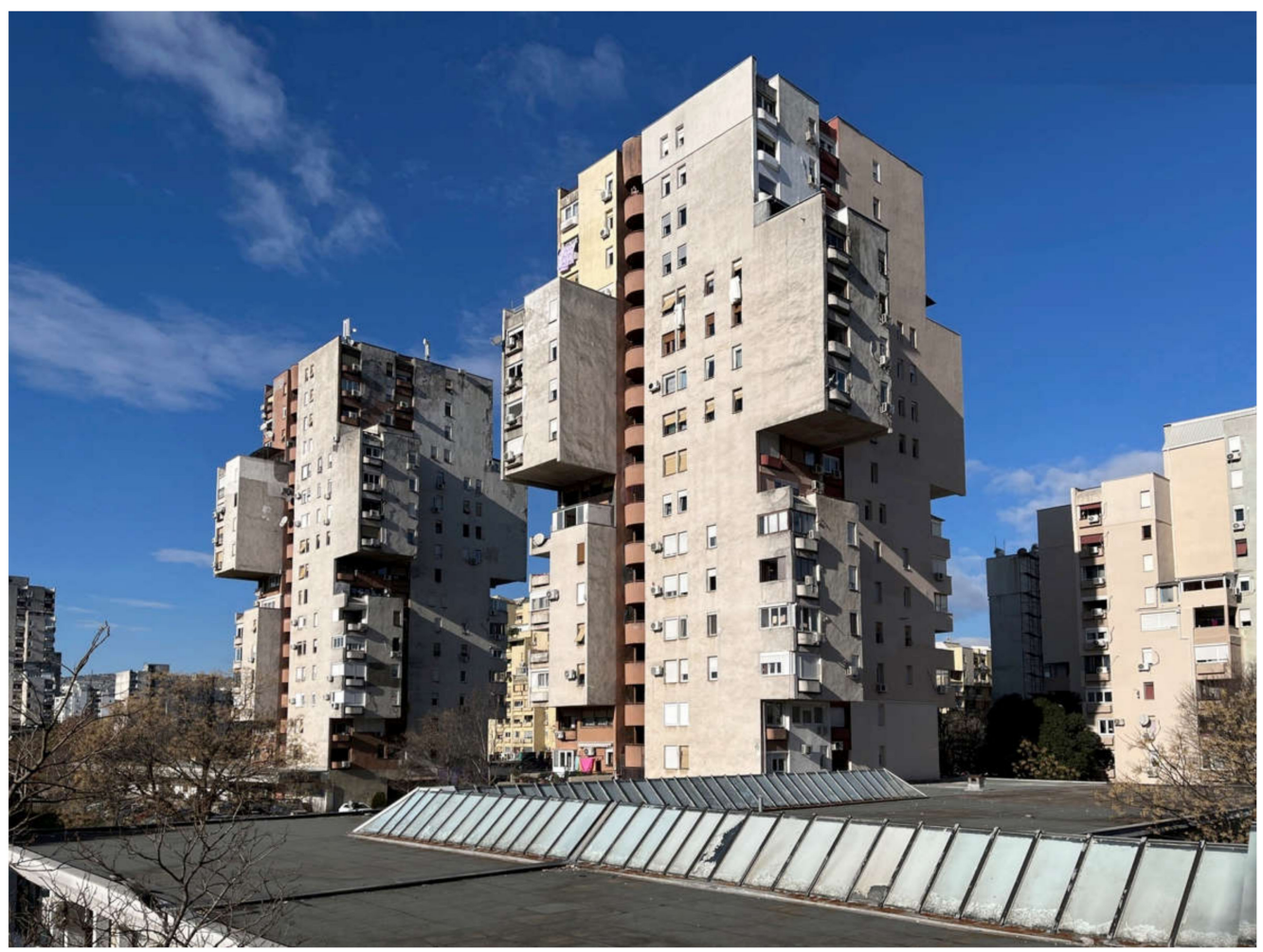

Figure 5. Large and unused connecting platform between two high-rises, above ground floor, suitable for landscaping and converting into green gardens and surfaces suitable for urban agriculture.

Application of M4: All Blok 5 apartments are equipped with loggias or terraces with concrete jardinières filled with soil; the project envisaged contact with nature at the level of each residential unit. Jardinières are more or less active depending on the personal preferences of residents, so we can conclude that this model guideline is already implemented and that it only requires activation of existing preconditions. Apartments on the top floors of cantilever outlets (eight in total) (Figure 6) have terraces of significant surface, which, as such, can be significantly activated as "natural oases" if they have not been transformed into closed residential space during the transition period. 

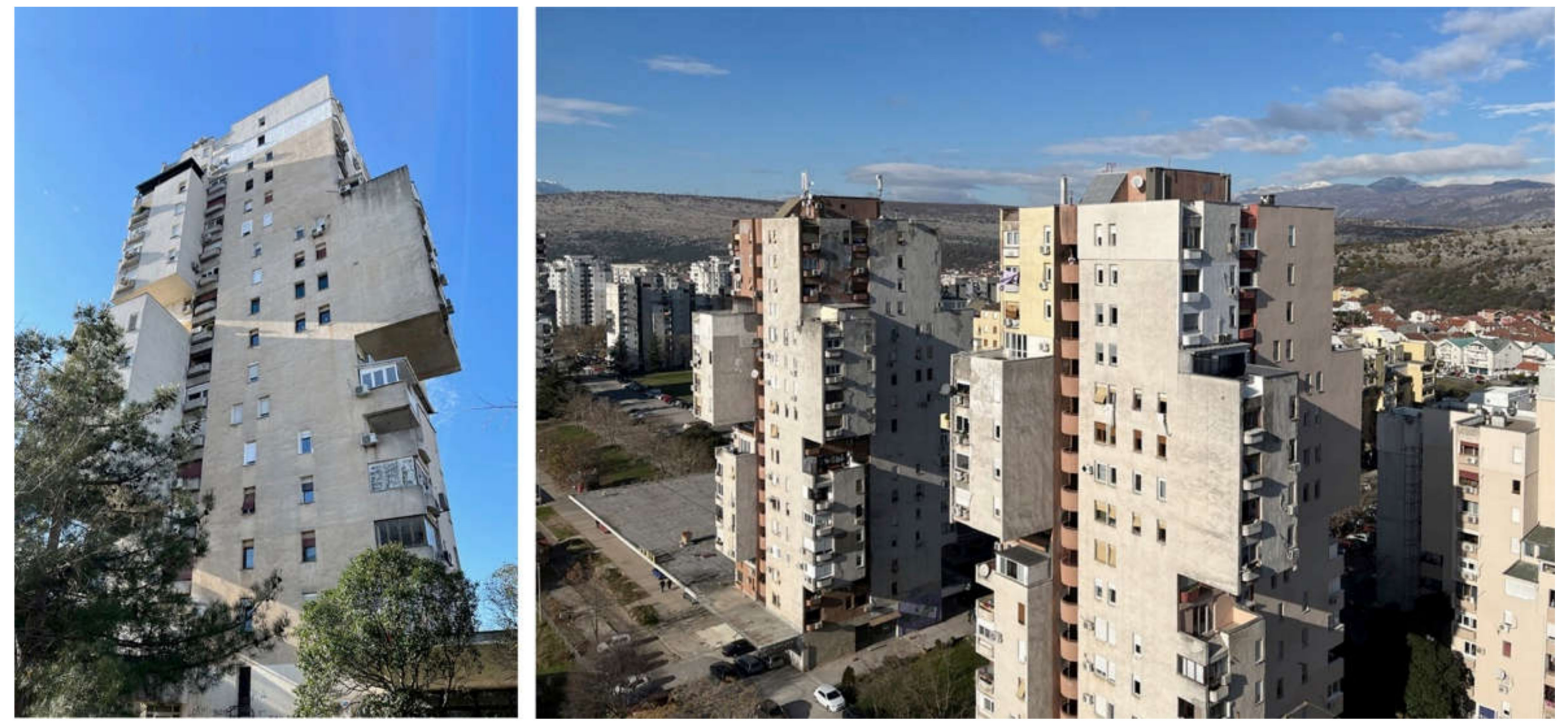

Figure 6. High-rises $\mathrm{C} 1$ and $\mathrm{C} 2$ : concrete jardinières within every apartment and open terraces on cantilever outlets.

Application of M5: Guideline M5 refers to the addition of external, prefabricated structures in order to provide common areas for socialization within the building in the cases of compact urban blocks, or, similarly, for enabling contact with nature. The application of this guideline to the selected building is not necessary (nor adequate) since the application of the previous four sets of guidelines is quite feasible, which would, in our opinion, result in an optimal level of residential resilience to pandemic conditions.

This completes the proposal of the application of the resilient residential model to the selected existing buildings in Podgorica. We find that the model can be applied in a satisfactory way at the level of all four basic guidelines, which would result in a resilient residential building in the context of the pandemic, and the functioning would be significantly improved even compared to pre-COVID-19 conditions. The tenants would thus receive significant common spaces for gathering in several places within the building and large urban gardens, which could be further activated through urban agriculture to the desired extent. All these spaces would represent engaging and quality environments for safe outdoors social activities and gatherings, even for occasional remote work, and their use would strengthen the sense of community, which is largely lost in the time of capitalism and everyday life of a consumer society. Practicing the right to one's own adequate housing is also feasible considering that the apartments were initially designed to be flexible and allow for significant changes within the same square footage by moving partitions between rooms, changing user needs over time or during the pandemic. We, therefore, conclude that the application of the model to the $\mathrm{C} 1$ and $\mathrm{C} 2$ buildings of Blok 5 is quite successful, largely due to the adequacy of the initial project, i.e., the residential area concept and theoretical strongholds that have been translated into practice at the level of the overall project.

\subsection{Application of the Model to Less Adequate Housing}

As most of the existing housing stock in Podgorica (and beyond) is less adequate for the implementation of the resilient residential model than the selected Blok 5 buildings, the question arises as to how to apply the model in these cases and whether the expected benefits will be sufficient.

Regarding flexibility of the apartment layouts, we expect certain limitations in the application of the M1 guideline since the projects of existing residential buildings most often did not deal with the adaptability of the apartment to the changing needs of the user. By limited application, we imply the insufficient adaptability of the space that would not include construction work in the apartment but would have to be limited exclusively 
to additional interior and detachable solutions, which could be introduced in cases of sufficient square footage and adequate layout of facade openings.

Limitations that we could expect in terms of the application of M2 are the lack of adequate indoor and outdoor spaces in buildings, which can be converted into a collective "extended" living room for tenants. Since such common areas need to be created in these cases, we suggest the following mechanisms:

(a) Takeover of adequate business space on the ground floor by the tenants, if existing, which is expected. This option would require providing access to the space from the common space in the building-through the entrance hall;

(b) Takeover of residential space within the building and its conversion into a common space for social activities;

(c) Adding a prefabricated structure to the main corpus of the building or between two adjacent buildings in the airspace of the inner courtyard of a compact urban block (combination with M5).

The M3 guideline is, in most cases, simply applicable if the building has a flat roof. Certainly, flat-roofed residential buildings were the dominant typology in Podgorica during the second half of the 20th century. Transitional housing, created in the last twenty years, is, however, mostly characterized by sloping roofs, which is why the application of this guideline refers to the activation of adequate vertical surfaces for the creation of vertical gardens or partial greening of open spaces for socialization.

M4, i.e., the realization of direct contact with nature at the level of each residential unit, can be achieved through prefabricated jardinières on the terraces if they were not provided by the initial project.

M5 is, to some extent, a complementary guideline, which has the greatest application in cases of compact urban fabric and closed blocks. We believe that it is possible, if necessary, to apply it to most residential buildings that are located in the dense urban areas of Podgorica. Access to these structures would need to be provided from the common areas.

We analyzed possible limitations of applying the resilient residential model to the existing housing in Podgorica. Reviewing the expected challenges, we conclude that, in all cases, the model can be applied in a capacity of $60-80 \%$ (three or four guidelines out of five); therefore, we believe that the model is sufficiently applicable even in less adequate scenarios than the selected Blok 5 buildings. Additionally, we believe that an application rate of $60-80 \%$ would significantly improve the quality of daily life of the residents during the ongoing pandemic and associated restrictions but also in general-in post-pandemic conditions.

\subsection{Complementing the Role of the Architect}

The model formulated in this paper, which we believe advocates a different and improved concept of multi-family residential buildings, requires a holistic design approach and consideration of the complexity of the relationship between users and their residential space in terms of spatial needs and their change over time or in the case of extraordinary lifestyle changes.

This "new" proposed concept of resilient residential space consequently requires complementing the role of the architect as one of the most important actors in the process. The architect represents a key mediator between the decision-makers, the investors, the very space that is created within the set framework and the end user, who should be its active user, practicing the right to adequate living space $[9,69]$. Therefore, the architect is primarily expected to provide a kind of education to all the actors in the process, which requires a broad and appropriate education and continuous learning from the architect himself. We believe that this would make a significant contribution to the affirmative attitude towards (residential) space at all levels; hence, it would make it possible to create the necessary preconditions for applying the model to existing housing stock, especially to the emerging buildings. 
From the aspect of design, within a more adequately regulated legal and planning framework, the additional task of the architect would be to design an initially more flexible and adaptable residential space, with the participation of interested users in the process of its creation, in terms of the professional articulation of their spatial needs. The results of the survey show that the flexibility of the apartment would be significant for $81.9 \%$ of the respondents, and as many as $96.4 \%$ would participate in the adjustment of the apartment to their own needs in the construction phase. This level of interest in adequate residential space and participation in its creation is very encouraging, especially in today's often inert transitional and consumer society. Therefore, complementing the role of the architect is additionally justified or even deemed essential.

\section{Discussion}

This paper has considered the COVID-19 pandemic as a sort of endurance and resilience test for the existing multi-family residential buildings in Podgorica in changed conditions and in the context of meeting the daily needs of the residential user. The challenge of this already two-year pandemic scenario for the functionality of residential buildings has pointed out significant shortcomings of the current housing concept, implying the need to rethink it and redefine it. At a time when an apartment often becomes a full-time habitat and the place of the realization of all life activities due to restrictions on leaving the residence, it becomes clear that the market value of the space must finally be replaced by its use value; i.e., increasing the use value of space becomes an imperative.

Adequate housing is considered to be of vital importance for user wellbeing, arguing its adequacy from the aspect of meeting the spatial needs of residents during the pandemic. As the resident is the central figure of this research, we investigated the daily user needs in the COVID-19 reality through a questionnaire in order to confirm preliminary assumptions and obtain input data to form a model for achieving residential resilience. The survey results show that users of residential buildings mostly lack contact with nature, i.e., the lack of a garden or yard and the possibility of staying outdoors during the lockdown. Precisely, these options are the reason why the residents of Podgorica who lived in a single-family residential building during lockdown presented much greater satisfaction with everyday life. For these reasons, in post-pandemic conditions, most would choose a single-family residential building or a residential building with green roof gardens, which would be used for various purposes by $74.3 \%$ of the respondents.

This knowledge of the attitudes of the respondents confirms the initial premise of this research, as well as the working definition of a residential building resilient to the restrictions imposed by the pandemic. Therefore, we believe that the improvement of residential use value, in order to achieve its resilience, can be done through the introduction of complementary contents-indoor and outdoor common areas for social activities within the building [22] as well as the conversion of flat roofs and/or adequate vertical areas into horizontal or vertical gardens [2,24], which can also be used for urban agriculture. We further argue that such improved housing provides a significantly higher level of quality of life [65,66], especially within pandemic restrictions, providing its occupants with a level of comfort similar to that achieved in a single-family residence. Such a building, with additional flexibility of the apartment units [22,25-28,53], at least to some extent, we consider to be an autonomous entity that can function smoothly in a pandemic scenario, providing its residents with a physical framework for a happy and healthy "new normal" life.

As each society produces its own space and that same space reciprocally shapes the same society [9], we believe that this transformed and adequate residential space would consequently increase the resilience of its residents and the community to the challenges they face today due to COVID-19. We consider this as a key and long-term benefit of improving residential space and the concept of housing in general.

The research briefly compared the key characteristics of residential buildings and residential areas from the period of self-managing socialism in Montenegro to today, the period of transition or neoliberal capitalism. The comparison also referred to the overall design 
process-from the very concept and thoroughness of addressing the housing issue to its most adequate resolving through planning and design. In comparison to the model for achieving resilience formulated in the research, we conclude that the housing concept present in theory and practice during self-managing socialism was far more adequate in terms of the affirmative attitude towards the residential space, housing, use value and humane dimension of residential buildings and areas, as well as in terms of their resilience to the ongoing and future challenges. The question arises as to whether the abandonment of earlier ideas and concepts, the general impoverishment of architectural work and thus residential buildings and the replacement of their use value with market value has permanently cost us the preconditions for healthy and happy living in a resilient city.

\section{Conclusions}

COVID-19 has brought along significant changes in everyday life globally. In the case of Montenegro, the pandemic has further potentiated the transitional socio-spatial issues that have been present for thirty years. In the period of transition, or already neoliberal capitalism, the space has become the most favorable medium for creating surplus profits. Although adequate housing is a prerequisite for the people's wellbeing, residential buildings are exactly the typology that is experiencing overproduction due to the transitional market policy, the overall impoverishment and reduction in goods solely viewed through market value at the same time. Due to the pandemic, the shortcomings of the existing housing stock are becoming more noticeable, which is why we see COVID-19 as a unique opportunity to accept the need to redefine the concept of housing and increase the use value of buildings in the context of resilience to ongoing, pandemic and future challenges.

By sublimating the conclusions of the theoretical part of the research and the results of the qualitative survey, we formulated a resilient residential model for the purposes of this paper to be applied to existing and future buildings in order to significantly increase their resilience to changed conditions in everyday pandemic life but in general as well. The model advocates for the integral application of a set of mechanisms that represent recognized values in the field of housing-flexible organization of an apartment as an imperative, common indoor and outdoor spaces for social interaction in small groups within the building and enabling direct contact with nature by introducing rooftop urban gardens. In order to test the theoretical assumptions in practice, we analyzed the application of the model to more and less adequate buildings in Podgorica. We found the application feasible in capacity not less than $60-80 \%$ in the worst-case scenario. This led to the conclusion that the model is sufficiently applicable in all scenarios and that its application would significantly improve the quality of daily life of the residents during the ongoing pandemic and associated restrictions but also in general-in post-pandemic conditions.

Even though the initial aim was to achieve long-term resilience of residential buildings in Podgorica, Montenegro, we assume that the findings of this research are applicable in much wider territorial contexts as well. The countries of former Yugoslavia share similarities regarding characteristics of housing stock, dating from self-managing socialism, but also from the period of transition to a certain extent [70-73]. Therefore, the proposed model could represent an adequate set of measures for addressing similar socio-spatial realities of the cities in the region in the context of the pandemic and post-pandemic era.

However, since the measures advocated for in the model represent universal and undoubted values in housing, we could argue its significance in general. The model could serve as the initial basis for achieving the resilience of existing and future residential buildings, further to be upgraded and complemented according to the specificities of the exact context.

Finally, we conclude that the issue of resilience of housing is a complex issue that requires a thorough and integral approach, and that achieving resilience regarding today's challenges of the pandemic scenario implies complementing the role of all actors in the process. We focused on complementing the role of the architect as a mediator between 
decision makers, planners, investors and, finally, the end-users of the space in the direction of the emancipation and education of all parties involved.

The findings of this research, in the end, could significantly contribute to the affirmative attitude towards residential space at all levels, resulting in a greater level of overall resilience and preconditions for the physical, mental and social wellbeing of the community.

Author Contributions: Conceptualization, M.B., I.R. and S.K.P.; methodology, M.B. and S.K.P.; formal analysis, M.B.; investigation, M.B. and I.R.; survey, M.B., I.R. and S.K.P.; writing-original draft preparation, M.B.; writing-review and editing, M.B., I.R. and S.K.P.; visualization M.B. and I.R., supervision, S.K.P., project administration, I.R. All authors have read and agreed to the published version of the manuscript.

Funding: This research received no external funding.

Institutional Review Board Statement: Not applicable.

Informed Consent Statement: Not applicable.

Data Availability Statement: Not applicable.

Conflicts of Interest: The authors declare no conflict of interest.

\section{References}

1. Quaglio, C.; Todella, E.; Lami, I.M. Adequate Housing and COVID-19: Assessing the Potential for Value Creation through the Project. Sustainability 2021, 13, 10563. [CrossRef]

2. Tokazhanov, G.; Tleuken, A.; Guney, M.; Turkyilmaz, A.; Karaca, F. How is COVID-19 Experience Transforming Sustainability Requirements of Residential Buildings? A Review. Sustainability 2020, 12, 8732. [CrossRef]

3. Whitaker, S. Did the COVID-19 Pandemic Cause an Urban Exodus? Available online: https://www.clevelandfed.org/en/ newsroom-and-events/publications/cfed-district-data-briefs/cfddb-20210205-did-the-covid-19-pandemic-cause-an-urbanexodus.aspx?source=content_type \%3Areact \%7Cfirst_level_url\%3Aarticle\%7Csection\%3Amain_content $\% 7$ Cbutton \%3Abody_ link\#D1 (accessed on 26 December 2021).

4. Haslag, P.H.; Weagly, D. From L.A. to Boise: How Migration Has Changed during the COVID-19 Pandemic. Available online: https:/ / papers.ssrn.com/sol3/papers.cfm?abstract_id=3808326 (accessed on 26 December 2021).

5. Hill, A. "We're Happier, Calmer": Why Young Adults are Moving out of Big Cities. Available online: https://www. theguardian.com/world/2021/feb/08/were-happier-calmer-why-young-adults-are-moving-out-of-big-cities (accessed on 26 December 2021).

6. They Had Reasons for Leaving the City. So Why Are Their Friends Mad? Available online: https://www.nytimes.com/2022/01/ 07 /realestate/pandemic-move-friends.html (accessed on 26 December 2021).

7. Power, R.E.; Rogers, D.; Kadi, J. Public housing and COVID-19: Contestation, challenge and change. Int. J. Hous. Policy 2020, 20, 313-319. [CrossRef]

8. Grijalba Castro, A.I.; Ramírez López, L.J. Sustainability and Resilience of Emerging Cities in Times of COVID-19. Sustainability 2021, 13, 9480. [CrossRef]

9. Bojović, M. Socio-Prostorne Manifestacije Transformacija Dobrog Življenja u Kontekstu Tranzicijskih Društvenih Promjena. Poseban Osvrt na Tranzicijsko Arhitektonsko Stvaralaštvo Crne Gore. Ph.D. Thesis, University of Sarajevo, Sarajevo, Bosnia and Herzegovina, 2021.

10. Cañizares, J.C.; Copeland, S.M.; Doorn, N. Making Sense of Resilience. Sustainability 2021, 13, 8538. [CrossRef]

11. Khaldi, Y. Urban Regeneration and Resilience: Evaluating the Impact of Regeneration Projects on Social Resilience in Glasgow's Sighthill. In Proceedings of the 2nd GeoMEast International Congress and Exhibition on Sustainable Civil Infrastructures, Sharm Elsheikh, Egypt, 15-19 July 2018. [CrossRef]

12. Meerow, S.; Newell, J.P.; Stults, M. Defining urban resilience: A review. Landsc. Urban Plan. 2016, 147, 38-49. [CrossRef]

13. Meerow, S.; Newell, J.P. Urban resilience for whom, what, when, where, and why? Urban Geogr. 2016, 40, 309-329. [CrossRef]

14. Urban Resilience. Available online: https://resilientcitiesnetwork.org/urban-resilience/ (accessed on 10 October 2021).

15. Lupíšek, A.; Růžička, J.; Tywoniak, J.; Hájek, P.; Volf, M. Criteria for evaluation of resilience of residential buildings in Central Europe. Int. Rev. Appl. Sci. Eng. 2018, 2, 89-93. [CrossRef]

16. Keck, M.; Sakdapolrak, P. What is social resiliece? Lessons learned and ways forward. Erdkunde 2013, 67, 5-18. [CrossRef]

17. Pelling, M. The Vulnerability of Cities: Natural Disasters and Social Resilience; Earthscan Publications Ltd.: London, UK, 2003.

18. Cutter, S.L.; Barnes, L.; Berry, M.; Burton, C.; Evans, E.; Tate, E.; Webb, J. A place-based model for understanding community resilience to natural disasters. Glob. Environ. Change 2008, 18, 598-606. [CrossRef]

19. Bouzarovski, S.; Salukvadze, J.; Gentile, M. A Socially Resilient Urban Transition? The Contested Landscapes of Apartment Building Extensions in Two Post-communist Cities. Urban Stud. 2011, 48, 2689-2714. [CrossRef] 
20. Frago, L. Impact of COVID-19 Pandemic on Retail Structure in Barcelona: From Tourism-Phobia to the Desertification of City Center. Sustainability 2021, 13, 8215. [CrossRef]

21. Aruga, K.; Islam, M.M.; Jannat, A. Does Staying at Home during the COVID-19 Pandemic Help Reduce CO2 Emissions? Sustainability 2021, 13, 8534. [CrossRef]

22. Tokazhanov, G.; Tleuken, A.; Durdyev, S.; Otesh, N.; Guney, M.; Turkyilmaza, A.; Karaca, F. Stakeholder based weights of new sustainability indicators providing pandemic resilience for residential buildings. Sustain. Cities Soc. 2021, 75, 103300. [CrossRef] [PubMed]

23. Arnold, P.; Quintas, N. Community-Led Housing in the Covid-19 Context. Available online: https://world-habitat.org/news / our-blog/community-led-housing-resisting-evictions-and-foreclosure-during-covid-19/ (accessed on 2 December 2021).

24. Dzhambov, A.M.; Lercher, P.; Browning, M.H.E.M.; Stoyanov, D.; Petrova, N.; Novakov, S.; Dimitrova, D.D. Does greenery experienced indoors and outdoors provide an escape and support mental health during the COVID-19 quarantine? Environ. Res. 2020, 196, 110420. [CrossRef]

25. The Impact of COVID-19 on Flexible Space. What the Future Holds in a Fast-Paced World Affected by the Pandemic. Available online: https://www.jll.de/content/dam/jll-com/documents/pdf/articles/covid-19-and-flexible-space-report.pdf (accessed on 18 November 2021).

26. Bettaieb, D.M.; Alsabban, R. Emerging living styles post-COVID-19: Housing flexibility as a fundamental requirement for apartments in Jeddah. Archnet-IJAR 2021, 15, 28-50. [CrossRef]

27. Gray, K. Flexible Spaces: How the Covid-19 Lockdown will Affect the Design of Our Future Homes. Available online: https:/ / www.standard.co.uk/homesandproperty/interiors/covid19-impact-interior-design-future-homes-a138601.html (accessed on 12 December 2021).

28. Lerner, M. A Home of the Future, Shaped by the Coronavirus Pandemic. Available online: https://www.washingtonpost.com/ realestate/a-home-of-the-future-shaped-by-the-coronavirus-pandemic/2021/08/18/5e3a2032-d426-11eb-ae54-515e2f63d3 7d_story.html (accessed on 12 December 2021).

29. Eco, U. The Open Work; Harvard University Press: Cambridge, CA, USA, 1989.

30. MoMA-Museum of Modern Art. Available online: https: / / www.moma.org/collection/works/800 (accessed on 20 October 2021).

31. Lefebvre, H. Le Droit a la Ville; Editions Anthropos: Paris, France, 1968.

32. UN-Habitat. The Right to Adequate Housing. Available online: https://unhabitat.org/sites/default/files/download-managerfiles/Right\%20to\%20adequate\%20housing.pdf (accessed on 25 October 2021).

33. UN-Habitat. Cities and Pandemics: Towards a More Just, Green and Healthy Future. Available online: https://unhabitat.org/ sites/default/files/2021/03/cities_and_pandemics-towards_a_more_just_green_and_healthy_future_un-habitat_2021.pdf (accessed on 1 November 2021).

34. Habraken, N.J. Supports: An Alternative to Mass Housing; Architectural Press: London, UK, 1972.

35. Habraken, N.J. The Uses of Levels. Keynote Address UNESCO Regional Seminar on Shelter for the Homeless Seoul. Available online: https://www.habraken.com/html/downloads/the_uses_of_levels.pdf (accessed on 12 October 2021).

36. Bojović, M.; Bajić Šestović, J. Self-managing Socialism and its Space: Blok 5 and Challenging Rhetoric of Flexibility. ACE Archit. City Environ. 2020, 15, 9213. [CrossRef]

37. Tschumi, B. Arhitektura i Disjunkcija; AGM: Zagreb, Croatia, 2004.

38. Lojanica, M. Zapisi sa crtaćeg stola. In Arhitektura Urbanizam; SACG: Belgrade, Serbia, 1975; pp. 18-22. ISSN 0004-1238.

39. Lefebvre, H. The Production of Space; Blackwell: Cambridge, UK, 1991.

40. Petranović, B. Istorija Jugoslavije 1918-1988: Socijalistička Jugoslavija 1945-1988; Nolit: Belgrade, Serbia, 1988.

41. Prostorno-Urbanisticki Plan Glavnog Grada Podgorica, do 2025. Godine. Available online: https://podgorica.me/db_files/ Urbanizam/PUP/pup.pdf (accessed on 26 December 2021).

42. Ždero, B. Problem Mještana Novih Naselja u PG: Beton Bez Hlada, Škola, Vrtića. Available online: https:/ /www.vijesti.me/ vijesti/drustvo/83423/problem-mjestana-novih-naselja-u-pg-beton-bez-hlada-skola-vrtica (accessed on 26 December 2021).

43. Šuvaković, M. Umetnost i Politika. Savremena Estetika, Filozofija, Teorija $i$ Umetnost u Vremenu Globane Tranzicije; Glasnik: Belgrade, Serbia, 2012.

44. Hirt, S. Iron Curtains: GATES, Suburbs and Privatization of Space in the Post-Socialist City; John Wiley \& Sons: Hoboken, NJ, USA, 2012.

45. Supek, R. Grad po Mjeri Čovjeka; Naprijed: Zagreb, Croatia, 1987.

46. Eykelbosh, A. COVID-19 Precautions for Multi-Unit Residential Buildings; National Collaborating Centre for Environmental Health: Winnipeg, MB, Canada, 2020; Available online: https://ncceh.ca/sites/default/files/COVID-19\%20Precautions\%20for\%20 Multiunit\%20Residential\%20Buildings\%20-\%20March\%2031\%202020.pdf (accessed on 26 December 2021).

47. Lovec, V.; Premrov, M.; Leskovar, V.Ž. Practical Impact of the COVID-19 Pandemic on Indoor Air Quality and Thermal Comfort in Kindergartens. A Case Study of Slovenia. Int. J. Environ. Res. Public Health 2021, 18, 9712. [CrossRef]

48. Meiss, A.; Jimeno-Merino, H.; Poza-Casado, I.; Llorente-Álvarez, A.; Padilla-Marcos, M.Á. Indoor Air Quality in Naturally Ventilated Classrooms. Lessons Learned from a Case Study in a COVID-19 Scenario. Sustainability 2021, 13, 8446. [CrossRef]

49. Dawwas, E.B.; Dyson, K. COVID-19 Changed Human-Nature Interactions across Green Space Types: Evidence of Change in Multiple Types of Activities from the West Bank, Palestine. Sustainability 2021, 13, 13831. [CrossRef]

50. Hawkley, L.C.; Cacioppo, J.T. Loneliness Matters: A Theoretical and Empirical Review of Consequences and Mechanisms. Ann. Behav. Med. 2010, 40, 218-227. [CrossRef] [PubMed] 
51. Hui, C.M. Green roof urban farming for buildings in high-density urban cities. In Proceedings of the Invited Paper for the Hainan China World Green Roof Conference, Hainan, China, 18-21 March 2011; pp. 18-21.

52. Cherry, N. Urban Gardening Has Taken Root, and It's Time for Cities to Encourage New Growth. Available online: https:/ /kinder. rice.edu/urbanedge/2021/03/31/pandemic-urban-gardening-has-taken-root-and-it-is-time-cities-encourage-new-growth (accessed on 26 December 2021).

53. Altaş, N.E.; Özsoy, A. Spatial Adaptability and Flexibility as Parameters of User Satisfaction for Quality Housing. Build. Environ. 1998, 33, 311-323. [CrossRef]

54. Özsoy, A.; Hasgul, E. User Involvment in Residential Environments: A Research About Flexible Housing. In Proceedings of the Conference Overcoming the Crisis: Integrating the Urban Environment, Tarragona, Spain, 19-22 June 2013.

55. Incremental Housing. Available online: http://web.mit.edu/incrementalhousing/ (accessed on 9 December 2021).

56. Lizarralde, G. Stakeholder participation and incremental housing in subsidized housing projects in Colombia and South Africa. Habitat Int. 2011, 35, 175-187. [CrossRef]

57. Van der Jagt, A.P.N.; RSzaraz, L.R.; Delshammar, T.; Cvejić, R.; Santos, A.; Goodness, J.; Buijs, A. Cultivating nature-based solutions: The governance of communal urban gardens in the European Union. Environ. Res. 2017, 159, 264-275. [CrossRef]

58. Stenseke, M. Local participation in cultural landscape maintenance: Lessons from Sweden. Land Use Policy 2009, 26, 214-223. [CrossRef]

59. Van den Bosch, M.; Sang, A.O. Urban natural environments as nature-based solutions for improved public health-A systematic review of reviews. Environ. Res. 2017, 158, 373-384. [CrossRef]

60. Ochoa, J.; Sanyé-Mengual, E.; Specht, K.; Fernández, J.A.; Bañón, S.; Orsini, F.; Magrefi, F.; Bazzocchi, G.; Halder, S.; Martens, D.; et al. Sustainable Community Gardens Require Social Engagement and Training: A Users' Needs Analysis in Europe. Sustainability 2019, 11, 3978. [CrossRef]

61. European Commission. Nature-Based Solutions. Available online: https:/ / ec.europa.eu/info/research-and-innovation/researcharea/environment/nature-based-solutions_en (accessed on 18 November 2021).

62. Ackerman, K.; Conard, M.; Culligan, P.; Plunz, R.; Sutto, M.P.; Whittinghill, L. Sustainable Food Systems for Future Cities: The Potential of Urban Agriculture. Econ. Soc. Rev. 2014, 45, 189-206.

63. Van Averbeke, W. Urban Farming in the Informal Settlements of Atteridgeville, Pretoria, South Africa. Water SA 2007, 33, 337-342. [CrossRef]

64. Säumel, I.; Reddy, S.E.; Wachtel, T. Edible City Solutions-One Step Further to Foster Social Resilience through Enhanced Socio-Cultural Ecosystem Services in Cities. Sustainability 2019, 11, 972. [CrossRef]

65. Samuelsson, K.; Barthel, S.; Colding, J.; Macassa, G.; Giusti, M. Urban Nature as a Source of Resilience during Social Distancing Amidst the Coronavirus Pandemic; OSF Prepr: Santa Barbara, CA, USA, 2020.

66. Flachs, A. Food for Thought: The Social Impact of Community Gardens in the Greater Cleveland Area. Elect. Green J. 2010, 1, 826. [CrossRef]

67. Whittinghill, L.; Rowe, D. The role of green roof technology in urban agriculture. Renew. Agric. Food Syst. 2011, 27, 314-322. [CrossRef]

68. Thomaier, S.; Specht, K.; Henckel, D.; Dierich, A.; Siebert, R.; Freisinger, U.; Sawicka, M. Farming in and on urban buildings: Present practice and specific novelties of Zero-Acreage Farming (ZFarming). Renew. Agric. Food Syst. 2014, 30, 43-54. [CrossRef]

69. Luck, R. Dialog in participatory design. Des. Stud. 2003, 24, 523-535. [CrossRef]

70. Čakarić, J.; Idrizbegović Zgonić, A. Nameless Settlements of Sarajevo. In Proceedings of the Conference: Material Science and Engineering, Bristol, UK, 1 December 2020; Volume 960. [CrossRef]

71. Gligorijević, Ž. Belgrade Planning in a New Cycle of Transition. In Proceedings of the 48th ISOCARP Congress, Perm, Russia, 10-13 September 2012; Available online: http:/ / www.isocarp.net/data/case_studies/2210.pdf. (accessed on 26 December 2021).

72. Grubović, L. Belgrade in Transition: An Analysis of Illegal Building in a Post-Socialist City. Ph.D. Thesis, London School of Economics and Political Science, London, UK, 2006.

73. Blau, E.; Rupnik, I. Project Zagreb: Transition as Condition, Strategy, Practice; Actar: Barcelona, Spain, 2007; ISBN 9788496540576. 